\title{
Neurotoxic Activation of Microglia Is Promoted by a Nox1- Dependent NADPH Oxidase
}

\author{
Cyril Chéret, ${ }^{1,2}$ Annie Gervais, ${ }^{1,2}$ Aurélia Lelli, ${ }^{1,2}$ Catherine Colin, ${ }^{1,2}$ Lahouari Amar, ${ }^{2,3}$ Philippe Ravassard, ${ }^{2,3}$ \\ Jacques Mallet, ${ }^{2,3}$ Ana Cumano, ${ }^{4}$ Karl-Heinz Krause, ${ }^{5}$ and Michel Mallat ${ }^{1,2}$ \\ ${ }^{1}$ Inserm, Unité Mixte de Recherche (UMR) 711, Institut Fédératif de Recherche 70, 75013 Paris, France, 2Université Pierre et Marie Curie Paris 06,75005 \\ Paris, France, ${ }^{3}$ Centre National de la Recherche Scientifique, UMR 7091, 75013 Paris, France, ${ }^{4}$ Inserm, U668, Institut Pasteur, 75724 Paris Cedex 15 , France, \\ and ${ }^{5}$ Biology of Ageing Laboratories, University of Geneva, 1211 Geneva, Switzerland
}

Reactive oxygen species (ROS) modulate intracellular signaling but are also responsible for neuronal damage in pathological states. Microglia, the resident CNS macrophages, are prominent sources of ROS through expression of the phagocyte oxidase which catalytic subunit Nox2 generates superoxide ion $\left(\mathrm{O}_{2}{ }^{-}\right)$. Here we show that microglia also express Nox1 and other components of nonphagocyte NADPH oxidases, including $\mathrm{p} 22^{\text {phox }}$, NOXO1, NOXA1, and Rac1/2. The subcellular distribution and functions of Nox 1 were determined by blocking Nox activity with diphenylene iodonium or apocynin, and by silencing the Nox1 gene in microglia purified from wild-type (WT) or Nox2-K0 mice. [Nox1-p22 ${ }^{\text {phox }}$ ] dimers localized in intracellular compartments are recruited to phagosome membranes during microglial phagocytosis of zymosan, and Noxl produces $\mathrm{O}_{2}{ }^{--}$in zymosan-loaded phagosomes. In microglia activated with lipopolysaccharide (LPS), Nox1 produces $\mathrm{O}_{2}^{--}$, which enhances cell expression of inducible nitric oxide synthase and secretion of interleukin- $1 \beta$. Comparisons of microglia purified from WT, Nox2-KO, or Nox1-K0 mice indicate that both Nox1 and Nox2 are required to optimize microglial production of nitric oxide. By injecting LPS in the striatum of WT and Nox1-K0 mice, we show that Nox1 also enhances microglial production of cytotoxic nitrite species and promotes loss of presynaptic proteins in striatal neurons. These results demonstrate the functional expression of Nox1 in resident CNS phagocytes, which can promote production of neurotoxic compounds during neuroinflammation. Our study also shows that Nox1- and Nox2-dependent oxidases play distinct roles in microglial activation and that Nox1 is a possible target for the treatment of neuroinflammatory states.

Key words: microglia; NADPH oxidase; Nox; nitric oxide; interleukin-1; LPS; neuroinflammation

\section{Introduction}

Microglia become activated in pathological contexts affecting neural cells. These cells may be neuroprotective through phagocytic elimination of pathogens, dying cells, and neurotoxic compounds, or through production of neurotrophic factors, but they may also promote neurodegeneration by producing proinflammatory or potentially neurotoxic effectors, including interleukin-1 $\beta$ (IL-1 $\beta$ ), nitric oxide (NO·), or reactive oxygen species (ROS) (Allan et al., 2005; Block et al., 2007; Hanisch and Kettenmann, 2007). Understanding the mechanisms that control microglial expression of neurotoxic effectors is crucial for the development of new therapeutic approaches to neuroinflammatory or neurodegenerative diseases.

Like other phagocytes, microglia express the phagocyte

Received July 29, 2008; revised Sept. 30, 2008; accepted 0ct. 2, 2008.

This work was supported by Inserm, Université Pierre et Marie Curie, and grants from European Leukodistrophy Association and Fédération pour la Recherche sur le Cerveau. We thank Dr. Françoise Morel for her generous gift of anti-p22 ${ }^{\text {phox }}$ antibodies, Dr. Chamsy Sarkis for stimulating discussion, and Drs. Merle Ruberg and Séverine Boillée for critical reading of this manuscript.

Correspondence should be addressed to Michel Mallat, Biologie des Interactions Neurones/Glie, Inserm, Unité Mixte de Recherche 711, Hôpital de la Salpêtrière, 47 Boulevard de I'Hôpital, 75651 Paris Cedex 13, France. E-mail: michel.mallat@upmc.fr.

DOI:10.1523/JNEUROSCI.3568-08.2008

Copyright $\odot 2008$ Society for Neuroscience $\quad 0270-6474 / 08 / 2812039-13 \$ 15.00 / 0$
NADPH oxidase (Sankarapandi et al., 1998; Bianca et al., 1999), an enzyme composed of four regulatory cytosolic components (p47 ${ }^{\text {phox }}, \mathrm{p} 67^{\text {phox }}, \mathrm{p} 40^{\text {phox }}$, and rac proteins) and a transmembrane flavocytochrome heterodimer consisting of the $\mathrm{p} 22^{\text {phox }}$ and the gp91 ${ }^{\text {phox }}$ (Nox2) catalytic subunit. Nox2 generates superoxide ion $\left(\mathrm{O}_{2}^{--}\right)$, which ensures the phagocytic neutralization of microorganisms (Nauseef, 2007), but also promotes neural cell death in animal models of neurodegenerative diseases and stroke (Walder et al., 1997; Wu et al., 2003, 2006). $\mathrm{O}_{2}^{--}$may be neurotoxic by fueling the formation of highly pro-oxidant hydroxyl free radical or peroxynitrite (Halliwell, 2006; Szabó et al., 2007). However, $\mathrm{O}_{2}^{--}$is also converted to hydrogen peroxide that primarily contributes to intracellular cell signaling processes through redox modulation of ion channels, enzymes, or transcription factors (Dröge, 2002; Veal et al., 2007). Studies using cultured microglia have shown redox modulations of microglial cell proliferation or function, which were attributed to ROS generated by the phagocyte oxidase (Pawate et al., 2004; Mander et al., 2006; Block et al., 2007). However, several homologues of Nox2 encoded by distinct genes (Nox1, Nox3, Nox4, Duox1, and Duox2) have been identified in nonphagocytic rodent and human cells (Bedard and Krause, 2007; Lambeth et al., 2007). Nox1 is predominantly expressed in colon epithelium, but was also detected in other peripheral tissues, including dorsal root ganglia 
Table 1. Primer sequences used for RT-PCR analyses of NADPH oxidases in microglia

\begin{tabular}{|c|c|c|c|}
\hline Primer & Sequence $\left(5^{\prime}\right.$ to $\left.3^{\prime}\right)$ & Amplicon (bp) & $\begin{array}{l}\text { Accession } \\
\text { number }\end{array}$ \\
\hline Nox2_for & CGAAGACAACTGGAAGGAA & 956 & NM_007807 \\
\hline Nox2_rev & GCTCCCACTAACATCACCAC & & \\
\hline Nox3_for & TTGTGGCACACTTGTTCAACCTGG & 493 & AY573240 \\
\hline Nox3_rev & TCACACGCATACAAGACCACAGGA & & \\
\hline Nox4_for & ATCACAGAAGGTCCCTAGCA & 615 & NM_015760 \\
\hline Nox4_rev & GGTCCAGAAATCCAAATCCA & & \\
\hline Duox1_for & CACCATTGGGACCCTTTGCTGTTT & 761 & XM_130483 \\
\hline Duox1_rev & AGCCTTTCATGAAGACCACCAGAA & & \\
\hline Duox2_for & AACCACCTATGTGGGCATCATCCT & 491 & XM_619808 \\
\hline Duox2_rev & AGCTGCCATGGATGATGATCAGGA & & \\
\hline Rac1_for & TGTGGTGGTGGGAGACGGAG & 528 & NM_009007.1 \\
\hline Rac1_rev & тTсTCTGTCCсCCTCCTGTC & & \\
\hline Rac2_for & GACAGGAGGGGGACAGAGAA & 254 & NM_009008.3 \\
\hline Rac2_rev & AGCGAGAAGCAGATGAGAAA & & \\
\hline p $22^{\text {phox }}$ for & GCTGCCCTCCACTTCCTGTT & 254 & NM_007806 \\
\hline p22 ${ }^{\text {phox }}$ rev & GCTGCCTCCTCTTCACCCTC & & \\
\hline p $40^{\text {phox }}$ for & AGAGCGACTTTGAGCAGCTT & 460 & AB002665 \\
\hline p40 ${ }^{\text {phox }}$ rev & TGTGGAGACACACCCTTGAT & & \\
\hline p47 $7^{\text {phox }}$ for & AGCCTGAGACATACCTGGTG & 446 & AB002663 \\
\hline p $47^{\text {phox }}$ rev & AGACTTCTGCAGATACATGG & & \\
\hline $\mathrm{p} 67^{\text {phox }}$ for & CAAGGCTACGGTTGTAGCAT & 465 & AB002664 \\
\hline p67 $7^{\text {phox }}$ rev & ACCTTGAGCATGTAAGGCAT & & \\
\hline
\end{tabular}

Accession numbers of the sequences and size of the corresponding amplicons are indicated. For, Forward; rev, reverse.

and in vascular cells (Suh et al., 1999; Bedard and Krause, 2007; Ibi et al., 2008). Like Nox2, Nox1 is a transmembrane protein which forms a heterodimer with $\mathrm{p} 22^{\text {phox }}$ and generates $\mathrm{O}_{2}{ }^{--}$ (Ambasta et al., 2004; Kawahara et al., 2005). Noxl activity requires rac proteins and is optimized in the presence of NOXO1 and NOXA1, two functional homologues of $\mathrm{p} 47^{\text {phox }}$ and $\mathrm{p} 67^{\text {phox }}$, respectively (Bánfi et al., 2003). Nox1 deletion was reported to increase survival in a mouse model of amyotrophic lateral sclerosis (ALS), but the cellular sources of Noxl and the mechanisms by which Nox1 may promote neural tissue damages remained undetermined (Marden et al., 2007).

In this study, we first show that microglia express catalytically active Nox1 in addition to the phagocyte oxidase. We then showed that activation of microglia with lipopolysaccharide (LPS), a component of Gram-negative bacteria commonly used to model proinflammatory and neurotoxic activation of microglia (Lehnardt et al., 2003; Qin et al., 2004), and injection of LPS in the brain induce IL- $1 \beta$ and NO production via Nox1, and favors peroxynitrite-mediated tyrosine nitration as well as loss of synapse proteins.

\section{Materials and Methods}

Animals. Wild-type (WT), CX3CR1-EGFP, Nox1, and gp91 ${ }^{\text {phox } / N o x 2 ~}$ knock-out (KO) mice (Pollock et al., 1995; Jung et al., 2000; Gavazzi et al., 2006) were on a C57BL/6J background. Nox2-KO mice were obtained from The Jackson Laboratory. WT mice were purchased from Iffa-Credo. Nox1-KO mice (Gavazzi et al., 2006) used in our experiments were derived from at least 10 backcrosses with WT C57BL/6J mice. All procedures were performed in accordance with the guidelines for care and use of experimental animals of the European Economic Community (ref 86/609/CEE) and approved by the ethics committee for animal experimentation in Ile-de-France.

Antibodies. Rabbit anti-p22 ${ }^{\text {phox }}$ antiserum (Campion et al., 2007) was a generous gift from Dr. Françoise Morel (GREPI, CNRS, Grenoble, France). Anti-LAMP1 rat monoclonal antibody developed by J. T. August was obtained from the Developmental Studies Hybridoma Bank developed under the auspices of the NICHD and maintained by the University of Iowa (Department of Biological Sciences, Iowa City, IA).
Commercial antibodies used include rat monoclonal anti-EGFP (Nacalai Tesque); anti-F4/80, anti-CD11b (M1/70.1), and anti-CD68 (Serotec); mouse monoclonal anti- $\beta$-actin (clone AC15, Sigma); rabbit polyclonal anti-Ibal (Wako Chemicals); anti-GFAP (DakoCytomation); antinitrotyrosine (Ntyr) (Upstate Biotechnology); anti-inducible NO synthase (iNOS) (Transduction Laboratory); and anti-synapsin (Synaptic Systems).

FACS sorting of microglial cells. Cerebral cortex quickly removed from killed 1-d-old (P1) heterozygous CX3CR1 ${ }^{\mathrm{EGFP} /+}$ mice was immersed in $0.1 \mathrm{M}$ ice-cold PBS, pH 7.4, dissected free of meninges, and mechanically dissociated. Viable cells expressing enhanced green fluorescent protein (EGFP) were sorted in a FACSAria analyzer (Becton Dickinson).

Reagents for cell cultures. Diphenylene iodonium salt (DPI) from Sigma and apocynin from VWR International were dissolved in sterile DMSO at $25 \mathrm{~mm}$ and $5 \mathrm{~m}$, respectively. DPI was stored at $-20^{\circ} \mathrm{C}$. LPS from Salmonella typhimurium (Sigma) was dissolved in sterile PBS at 1 $\mathrm{mg} / \mathrm{ml}$ and stored at $-20^{\circ} \mathrm{C}$. Zymosan A (Sigma) was opsonized with fetal calf serum (FCS). All other components of the culture media, including FCS with low endotoxin content $(<0.05 \mathrm{ng} / \mathrm{ml})$, were from Invitrogen. Cells were cultured in plastic dishes (TPP).

Microglial cell cultures. Cultured microglial cells were derived from the cerebral cortex of 1-d-old C57BL/6J, Nox1-KO, or Nox2-KO mice (P1), according to previously described procedures (Théry et al., 1991). Highly pure $(>99 \%)$ microglia were isolated from 2-week-old glial primary cultures grown in DMEM supplemented with $10 \%$ FCS. Purified microglia were washed three times in DMEM, seeded in DMEM plus 10\% FCS, and cultured for $2 \mathrm{~d}$ before any treatment with LPS, FCS-opsonized Zymosan A, DPI, or apocynin.

siRNA and lentiviral shRNA silencing of the Noxl gene in microglial cells. BV2 cell clones overexpressing Nox1 were selected by transfection of parental BV2 cells with a pcDNA3.1 plasmid encoding the mouse Nox1 cDNA under the control of the CMV promoter (Bánfi et al., 2003). siRNA oligomers specific for Nox1 (Dharmacon) or luciferase (used as a negative control; Qiagen) were transfected using Jetsi carrier (Qbiogene) and Nox1 gene silencing was assessed by RT-PCR analysis. A silencing siRNA sequence was used to design a short hairpin (sh) RNA specific for Nox1 (shNox1). A control shRNA (shCtrl) was designed from a 3 basemutated form of the siNoxl sequence. shNoxl and shCtrl sequences were inserted under the control of the human U6 promoter into a pTrip$\Delta$ U3-U6-PGK-EGFP-WPRE vector (Philippe et al., 2006). Lentiviral vectors shNoxl and shCtrl were generated by transfection of HEK293T cells with the vector plasmid (pTrip-shNox1 or pTrip-shCtrl, respectively), the transcomplementation plasmid p8,7 and the $\mathrm{pHCMV-G}$ plasmid encoding the vesicular stomatitis virus glycoprotein as described previously (Philippe et al., 2006). Lentiviral vectors shCtrl and shNox1 were applied to freshly purified microglial cells at equivalent numbers of transduction units (TU), as assessed by EGFP labeling.

Detection of superoxide ion. Cellular production of $\mathrm{O}_{2}{ }^{--}$was visualized through the $\mathrm{O}_{2}{ }^{--}$-specific oxidation of hydroethidine (Bindokas et al., 1996). Microglial cells cultured in 8-well Labtek slides were incubated with hydroethidine ( $10 \mu \mathrm{M}$, Molecular Probes) for $45 \mathrm{~min}$, in the presence or the absence of LPS $(1 \mu \mathrm{g} / \mathrm{ml})$ or opsonized zymosan $\left(3 \times 10^{6}\right.$ particles per ml) with or without DPI $(1 \mu \mathrm{M})$. The cells were washed, fixed with $4 \%$ paraformaldehyde (PFA) and counterstained with Hoechst 33342 dye $(2 \mu \mathrm{g} / \mathrm{ml}$ in PBS) before labtek slide mounting in Fluoromount G (Southern Biotechnology Associates). Fluorescence images were captured using a Zeiss Axio ImagerZ1 fluorescence microscope (excitation: $530-585 \mathrm{~nm} /$ Emission $>615 \mathrm{~nm}$ ) equipped with a $40 \times \mathrm{NA}$ 0.75 EC Plan-Neo Fluar objective (Zeiss). Fluorescence levels of oxidized hydroethidine were quantified using NIH Image 1.37 software and normalized to the number of Hoechst-stained nuclei (25-40 cells per microscopic fields). Generation of $\mathrm{O}_{2}^{--}$in microglia engulfing zymosan was also visualized through the $\mathrm{O}_{2}{ }^{\cdot-}$-mediated reduction of nitroblue tetrazolium (NBT). Microglia were incubated with opsonized zymosan for 45 $\mathrm{min}$, then NBT ( $1.6 \mathrm{mg} / \mathrm{ml}$, Sigma) was added to the medium for the last $15 \mathrm{~min}$, before PFA fixation. Images were captured under differential interference contrast (DIC) or transmitted light using a DMRB microscope (Leica Microsystems) equipped with a $100 \times$ NA 1.40 oilimmersion objective. 


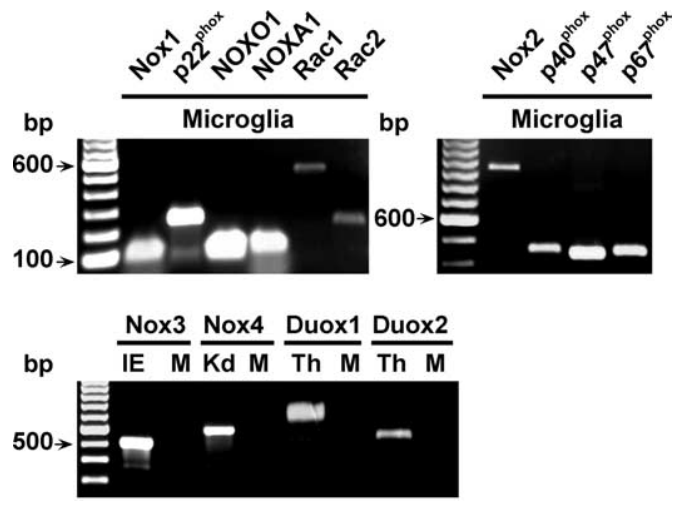

Figure 1. Microglia express the genes encoding Nox1- and Nox2-dependent NADPH oxidases. Ethidium bromide-stained agarose gels of reverse transcription-PCR products generated from Nox1, p22 ${ }^{\text {phox }}$, NOX01, NOXA1, Rac1, Rac2, Nox2, p40 ${ }^{\text {phox }}$, p47 ${ }^{\text {phox }}$, and p67 $7^{\text {phox }}$ mRNA in microglia purified by FACS from CX3CR1 ${ }^{\text {GGP/+ }}$ mice or from Nox3, Nox4, Duox1, or Duox2 mRNA in FACS-purified CX3CR1 ${ }^{\mathrm{EGFP} /+}$ microglia (M), inner ear from P3 mice (IE), kidney from 16-d-old mice embryos (Kd), or adult mouse thyroid (Th). IE, Kd, and Th were from WT mice and were used as positive controls.

Microglial production of IL-1 $\beta$ and NO. Microglial cells cultured in 96-well plates $\left(5 \times 10^{4}\right.$ cells seeded per well $)$ were treated with or without LPS $100 \mathrm{ng} / \mathrm{ml}$ for $16 \mathrm{~h}$ and levels of IL- $1 \beta$ in the culture media were determined using commercially available ELISA (R\&D Systems). NO• production was assessed by determination of nitrite levels using the colorimetric Griess method.

Assessment of cell survival. Microglia cultured in 96-well plates were fixed with PFA added directly to the culture medium for 10 min at RT (final concentration 4\%) and stained with Hoechst 33342 dye in PBS. Images were captured using an inverted Leica DMRiB fluorescence microscope (Leica Microsystems). The number of morphologically intact cell nuclei was determined by computer-assisted counts using ImageJ software in microscopic fields covering $6 \%$ of the well surface.

Immunocytodetection of $222^{\text {phox }}, E G F P$, and LAMP1. Cells cultured in 8-well Labtek slide were fixed with 4\% PFA for $10 \mathrm{~min}$ at RT before sequential incubations ( $1 \mathrm{~h}$ at RT) with rabbit anti-p22 ${ }^{\text {phox }}$ antiserum diluted 1:300 in PBS, $0.2 \%$ BSA, $0.05 \%$ saponin, Alexa Fluor 594- or Alexa Fluor 488-conjugated anti-rabbit IgG antibodies (1:1000, Invitrogen), rat monoclonal anti-EGFP antibody (1:1000) or rat monoclonal anti-LAMP1 antibody (1:20), and Alexa Fluor 488- or Alexa Fluor 594conjugated anti-rat IgG (Invitrogen). Cell nuclei were stained with Hoechst 33342 dye. Slides were mounted in Fluoromount G, and images were acquired at room temperature using an AxioImagerZ1 fluorescence microscope (Zeiss) or using a confocal microscope SP2 AOBS (Leica Microsystems) equipped with a $63 \times$ NA 1.40 oil-immersion objective. Controls performed by substituting primary antibodies with rabbit nonimmune serum or unrelated monoclonal antibodies of matched isotypes were negative.

Reverse transcription PCR analyses. RNA was extracted from pellet of FACS-purified CX3CR $1^{\mathrm{EGFP} /+}$ cells or from cultured microglia using the Absolutely RNA Microprep Kit (Stratagene). RNA from FACS-purified cells was amplified with the Smart mRNA Amplification Kit (Clontech). Reverse transcription using random primers was performed with Superscript II (Invitrogen). Standard PCR amplification was performed using TaqDNA polymerase from Qiagen, oligonucleotides listed in Table 1 and $\mathrm{RT}^{2}$ PCR primer sets purchased from SuperArray Bioscience (proprietary primers; sequence not disclosed) for mouse Nox1 (producing a 90 bp amplicon, RefSeq accession number: NM_172203), NOXO1 (83 bp amplicon, NM_027988), and NOXA1 (103 bp amplicon, NM_172204). PCR conditions were: $2 \mathrm{~min}$ at $95^{\circ} \mathrm{C}$, amplification by $30-35$ cycles of denaturation at $95^{\circ} \mathrm{C}$ for $45 \mathrm{~s}$, annealing at $53^{\circ} \mathrm{C}$ to $60^{\circ} \mathrm{C}$ for $45 \mathrm{~s}$, and extension at $72^{\circ} \mathrm{C}$ for $45 \mathrm{~s}$, followed by a final elongation step at $72^{\circ} \mathrm{C}$ for $10 \mathrm{~min}$. PCR products were separated on $1.8 \%$ agarose gels and visualized with ethidium bromide.

Quantitative real-time PCR was performed using $\mathrm{RT}^{2} \mathrm{PCR}$ primer sets
(SuperArray Bioscience Corporation) for mouse Nox1, NOXO1, NOXA1, IL-1 $\beta$ (accession number: NM_008361), iNOS (NM_010927), and p22 ${ }^{\text {phox }}$ (NM_007806), and Brilliant QPCR SYBR green Mix in a MX3000P (Stratagene). The samples were amplified by 40 cycles $\left(95^{\circ} \mathrm{C}\right.$ for $60 \mathrm{~s} ; 60^{\circ} \mathrm{C}$ for $30 \mathrm{~s}$ ) and analyzed using the $2^{-\Delta(\Delta \mathrm{Ct})}$ method. HPRT served as a reference gene using the following primer sequences: forward 5' -CCT AAG ATG AGC GCA AGT TGA A-3' and reverse 5' -CCA CAG GAC TAG AAC ACC TGC TAA-3' (accession number: NM_013556.2). Western blot analyses. Cultured microglia were lysed in $1 \%$ SDS preheated to $95^{\circ} \mathrm{C}$. Lysates were further heated to $95^{\circ} \mathrm{C}$ for $1 \mathrm{~min}$. Protein concentrations were quantified by the bicinchoninic acid assay (Sigma). Total microglial cell extracts were resolved by $7.5 \%$ SDS-PAGE, transferred to a nitrocellulose membrane and processed for immunodetection as described previously (S. Qin et al., 2006). Binding of rabbit polyclonal anti-iNOS (diluted 1:1000) and mouse anti- $\beta$-actin antibodies (1:4000) were detected by enhanced chemiluminescence (Perbio) using horseradish peroxidase (HRP)-linked anti-mouse IgG or anti-rabbit IgG (GE Healthcare). Western blot bands of iNOS were quantified and normalized against $\beta$-actin using ImageJ software.

LPS injection and immunohistofluorescence. Twenty-one-week-old male mice ( $25 \mathrm{~g}$ weight) obtained from two breeding pairs of Nox1 ${ }^{+/-}$ females and Nox1 ${ }^{\mathrm{Y} /-}$ males were genotyped. Five Nox1 ${ }^{\mathrm{Y} /+}(\mathrm{WT})$ and five Nox1 ${ }^{\mathrm{Y} /-}$ (Nox1-KO) male littermates were used for the experiments. Four micrograms of LPS diluted in $1 \mu \mathrm{l}$ of PBS were injected unilaterally into the brain of deeply anesthetized mice, using stereotaxic coordinates for the striatum: $+0.6 \mathrm{~mm}$ anterior-posterior, $1.8 \mathrm{~mm}$ lateral, and $3 \mathrm{~mm}$ depth relative to the bregma.

Mice were deeply anesthetized and perfused with $4 \%$ PFA $4 \mathrm{~d}$ after the injections. Brains were postfixed $2 \mathrm{~h}$ in the same fixative and processed for immunohistochemistry as described previously (S. Qin et al., 2006). Briefly, coronal sections ( $16 \mu \mathrm{m}$ thick) blocked with goat serum were incubated with rabbit polyclonal anti-Iba1 (diluted 1:400), rabbit antiGFAP antibodies (1:200), or rabbit polyclonal anti-synapsin antibodies (1:400). Bound antibodies were detected with Alexa Fluor 488conjugated anti-rabbit IgG. For double-immunofluorescence staining of microglia, a combination of rat monoclonal antibodies specific for different macrophage markers was used to optimize visualization of the cells. Goat serum blocked sections were incubated with rabbit polyclonal anti-Ntyr (diluted 1:400), and primary antibodies were revealed with Alexa Fluor 488-conjugated anti-rabbit IgG. Sections were then incubated with a mixture of rat monoclonal anti-F4/80 (1:100), anti-CD11b (1:400), and anti-CD68 (1:400) antibodies before incubation with an Alexa Fluor 594-conjugated goat anti-rat IgG.

Labeled brain sections were mounted in Fluoromount G, and images were captured using a Zeiss AxioImagerZ1 microscope equipped with the apotome system (Zeiss). A $10 \times$ NA 0.50 Fluar objective was used to capture images for quantitative analyses. For each animal, the number of immunostained microglial cells and the proportion of microglial cells stained with anti-Ntyr were determined in microscopic fields $\left(9 \times 10^{4}\right.$ $\mu \mathrm{m}^{2}$ area) acquired in six sections of a cerebrocortical region centered on the lesional tract and extending over $384 \mu \mathrm{m}$ on the anteroposterior axis.

Synapsin-stained areas were assessed in 6 sections of a striatum region extending over $560 \mu \mathrm{m}$ in the anteroposterior axis. Square regions $\left(6.25 \times 10^{4} \mu \mathrm{m}^{2}\right.$ area $)$ in microscopic fields localized $300 \mu \mathrm{m}$ ventral to the injection site or in the matched contralateral region were used for quantification. Images were acquired with equal exposure time, without saturation. A threshold was assigned for each animal to eliminate background fluorescence before analysis using ImageJ Software. Synapsin stained area in region ipsilateral to the injection site was expressed relative to the matched contralateral region in each animal to correct for any shift in the anteroposterior axis during sampling.

\section{Results}

\section{Expression of Nox genes in microglia}

To investigate microglial expression of NADPH oxidase-related genes in vivo, we used the CX3CR1-EGFP knock-in mice (Jung et al., 2000), in the CNS of which enhanced green fluorescent protein (EGFP) is selectively expressed by microglia. EGFP-positive 
microglia were purified by FACS from freshly dissociated forebrain of newborn heterozygotes and the expression of Nox proteins and Nox regulatory subunits was determined by RT-PCR analyses. Both Nox2 and Nox1 transcripts were clearly expressed by microglia from newborn mice, whereas Nox3, Nox4, Duox1, or Duox2 transcripts were not detectable (Fig. 1). In addition to Nox1 and Nox2, FACS-purified microglia expressed the full set of genes required for optimal activity of Nox1, including $\mathrm{p} 22^{\text {phox }}$ NOXO1, NOXA1, and Rac1/2. We also detected transcripts of the genes encoding cytosolic regulatory units $\mathrm{p} 47^{\text {phox }}, \mathrm{p} 67^{\text {phox }}$, and $\mathrm{p} 40^{\text {phox }}$, which associate with Nox2 in the active form of the phagocyte oxidase. To further analyze the expression of Nox genes and determine their function, we used microglia purified from primary cultures, which were prepared from the cerebral cortex of newborn wild-type (WT) or Nox2-deficient mice (Nox2-KO). RTPCR experiments confirmed that similar to FACS-purified CX3CR1 ${ }^{\mathrm{EGFP} /+}$ cells, microglia derived from WT or Nox2-KO mice expressed transcripts for Nox1, NOXO1, NOXA1, and the genes encoding the phagocyte oxidase components. We also confirmed that neither WT nor Nox2-KO microglia expressed Nox3, Nox4, or Duox transcripts (data not shown). Real time-PCR comparisons of transcript levels in WT and Nox2-KO microglia showed that Nox2 gene inactivation had no significant effect on the expression of Nox1, NOXO1, NOXA1, and p22 ${ }^{\text {phox }}$ transcripts (supplemental Fig. 1, available at www.jneurosci.org as supplemental material). Thus microglia express in vivo and in vitro the genes encoding the components of Nox1- and Nox2dependent NADPH oxidases.

\section{Distribution of Nox-associated $\mathbf{p} 22^{\text {phox }}$}

The association of either Nox1 or Nox 2 with $\mathrm{p} 22^{\text {phox }}$ is required for Nox activity and stabilizes the expression of both Nox and $\mathrm{p} 22^{\text {phox }}$ (Parkos et al., 1989; DeLeo et al., 2000; Ambasta et al., 2004; Kawahara et al., 2005). [Nox-p22 $2^{\text {hox }}$ ] heterodimers are formed independently of the enzyme activation (Bedard and Krause, 2007) and are therefore expected in unstimulated microglia. To determine the subcellular distribution of functional Nox2 and Nox1 bound to $\mathrm{p} 22^{\text {phox }}$ in microglial cells, we used an antibody specific for p $22^{\text {phox }}$ (Campion et al., 2007). In WT microglia, anti-p22 $2^{\text {phox }}$ immunoreactivity was observed at the plasma membrane and on intracellular vesicles, some of which expressed the lysosome marker LAMP1 (Fig. 2A). In Nox2-KO microglia, the plasma membrane was not stained, although $\mathrm{p} 22^{\text {phox }}$ was clearly detected in vesicles, including LAMP1-positive lysosomes (Fig. $2 \mathrm{~A}$, white arrowheads), albeit at lower levels than in WT cells. Despite
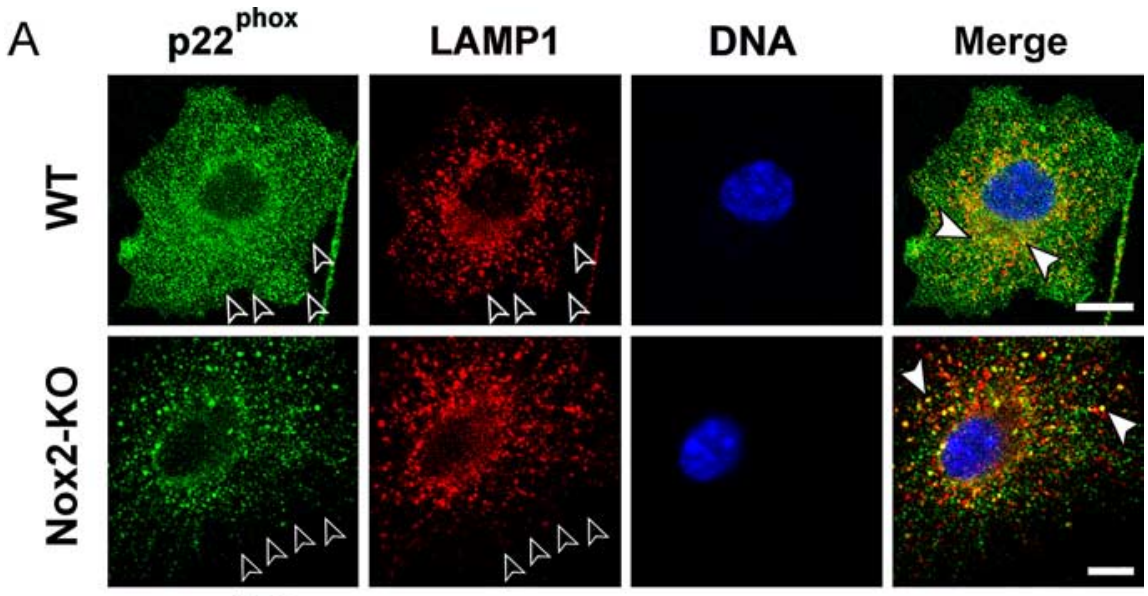

B

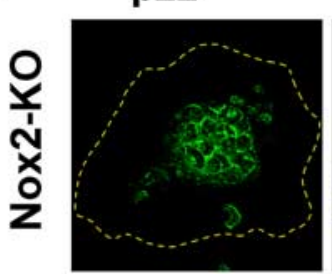

DNA
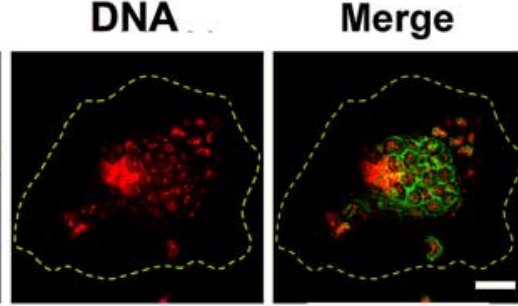

C

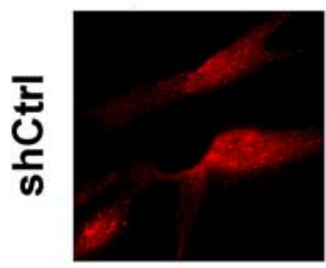

EGFP

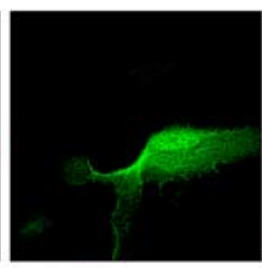

DNA

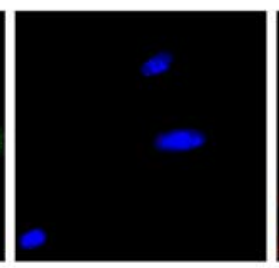

Merge
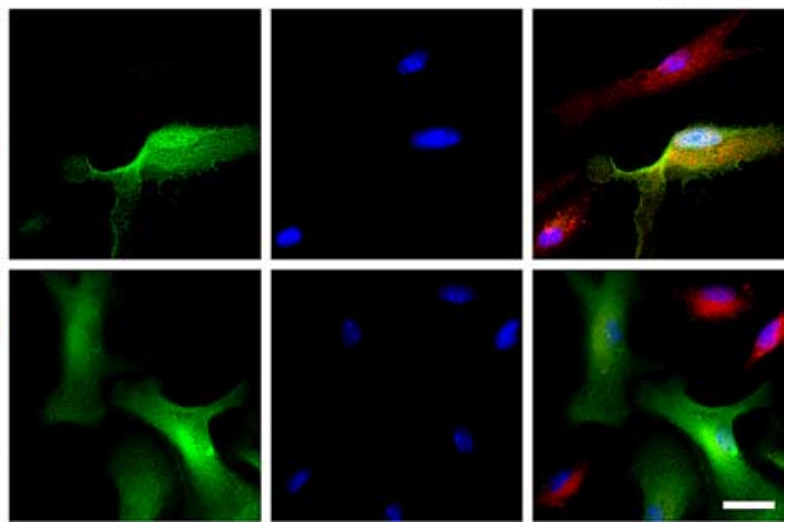

Figure 2. Nox1- and Nox2-dependent localization of $\mathrm{p} 22^{\text {phox }}$ in microglia. $A$, Codetection of $\mathrm{p} 22^{\text {phox }}$ (anti-p22 ${ }^{\text {phox }}$, green), lysosomes (anti-LAMP1, red), and nuclei (Hoechst 33342, blue) in cultured WT or Nox2-K0 microglia. Plasma membranes are outlined by open arrowheads. White arrowheads point to lysosomal p $22^{\text {phox }}$ in merged views (confocal microscopy). Scale bars, $10 \mu \mathrm{m}$. B, Detection of p22 ${ }^{\text {phox }}$ (green) and nucleic acid (Hoechst staining, blue fluorescence converted to red) in a Nox2-K0 murine microglial cell after microglial phagocytosis of yeast particles (zymosan). The plasma membrane is outlined in yellow. Cultured cells were incubated with zymosan for 45 min before fixation and staining. Note the localization of $\mathrm{p} 22^{\text {phox }}$ in phagosome membranes surrounding stained nucleic acid of yeast particles (confocal microscopy). Scale bar, $10 \mu \mathrm{m}$. C, Suppression of p22 ${ }^{\text {phox }}$ expression in Nox2-K0 microglial cells transduced with shNox1. Cultures of purified Nox2-K0 microglia were transduced with lentiviral shNox 1 or shCtrl and cultured for $3 \mathrm{~d}$ before fixation and codetection of p22 ${ }^{\text {phox }}$ (anti-p22 ${ }^{\text {phox }}$, red) and EGFP (anti-EGFP, green). Cells transduced with lentiviral shRNA express EGFP. Scale bar, $20 \mu \mathrm{m}$.

the apparent lack of $\mathrm{p} 22^{\text {phox }}$ immunoreactivity at the plasma membrane, engulfment of opsonized zymosan by Nox2-KO microglia triggered a marked redistribution of $\mathrm{p} 22^{\text {phox }}$ immunoreactivity to the phagosomes (Fig. $2 \mathrm{~B}$ ). The redistribution of $\mathrm{p} 22^{\text {phox }}$ to phagosomes was also obvious in WT microglia engulfing zymosan (data not shown). These results strongly suggested that at least part of microglial Nox2 is localized in the plasma membrane whereas Noxl is found in intracellular vesicular compartments including lysosomes, and can be recruited to phagosomal membranes.

Antibodies selectively reacting with murine Nox1 are currently unavailable. Therefore, to confirm that $\mathrm{p} 22^{\text {phox }}$ detection 

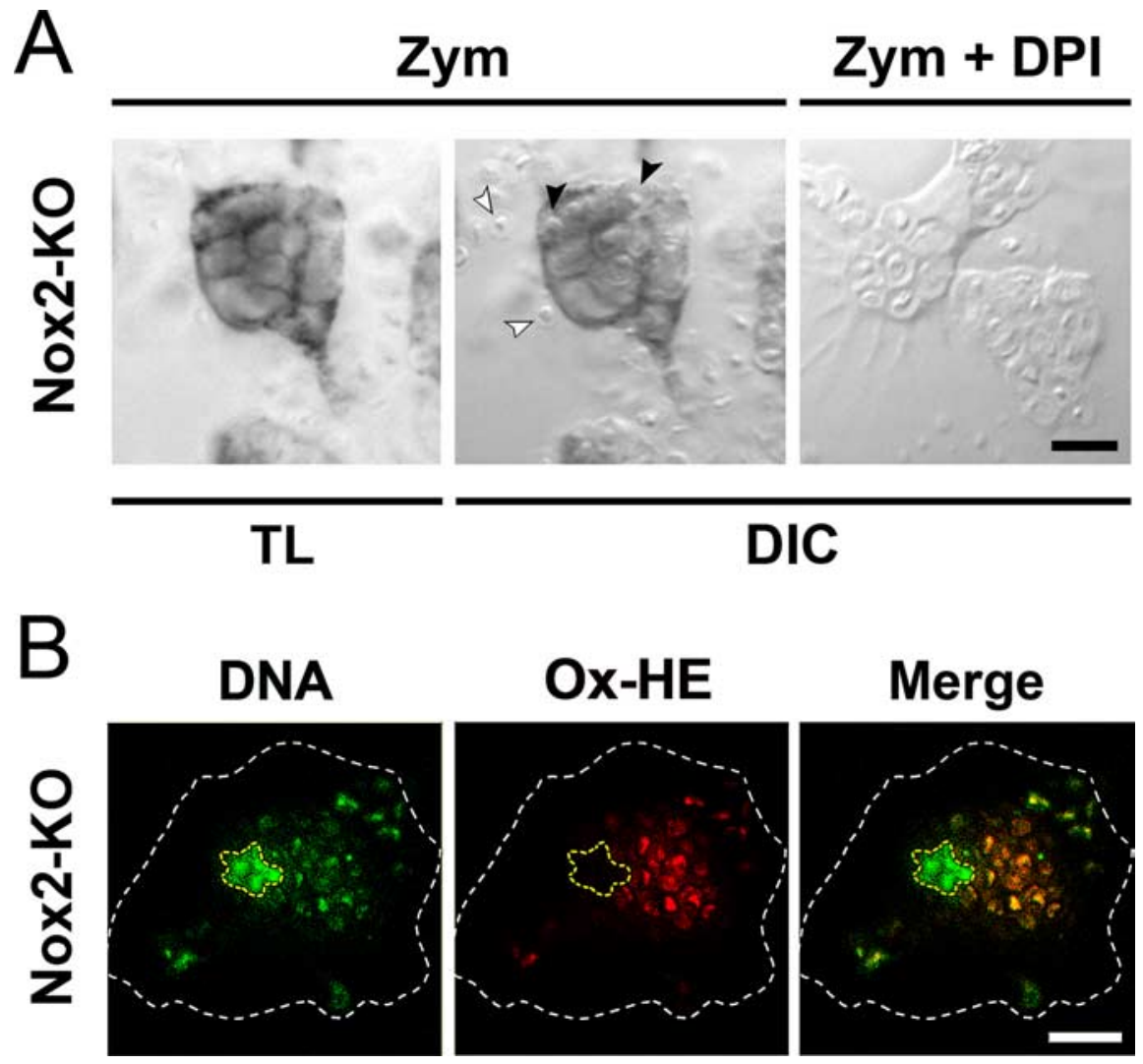

Figure 3. Detection of phagosomal $\mathrm{O}_{2}{ }^{-}$in Nox2-K0 microglia engulfing zymosan. $A$, Cultured Nox2-K0 microglia were incubated for $30 \mathrm{~min}$ with zymosan (Zym) in the absence or the presence of DPI, before addition of NBT to the culture for $15 \mathrm{~min}$. TL, Transmitted light. DIC, Differential interference contrast. White and black arrowheads indicate extracellular and engulfed yeast particles, respectively. The dark blue formazan deposit overlying the phagosomal membrane is not observed in DPI-treated cells. $\boldsymbol{B}$, Red fluorescence emitted by oxidized hydroethidine ( $0 \mathrm{x}-\mathrm{HE}$ ) in a Nox2-K0 microglial cell (same cell as in Fig. 2 B) after a $45 \mathrm{~min}$ incubation with zymosan in the presence of cell-permeant hydroethidine. The DNA of the cell and engulfed zymosan were counterstained with Hoechst 33342 (blue fluorescence converted to green), and the cell nucleus and the plasma membrane are outlined in yellow and white, respectively. Ox-HE fluorescence is colocalized with the DNA of engulfed zymosan (confocal microscopy). Scale bars, $10 \mu \mathrm{m}$.

in Nox2-KO microglia reflected distribution of [Nox1-p22 ${ }^{\text {phox }}$ ] heterodimers, we investigated how shRNA-based suppression of the Nox1 gene affects the distribution of $\mathrm{p} 22^{\text {phox }}$. The Nox1 gene was silenced in primary microglia by transduction of the cells with a lentiviral vector encoding a shRNA specific for Nox1 (shNox1) together with an EGFP reporter gene allowing visualization of transduced cells. A lentiviral vector encoding a mutated form of shNoxl (shCtrl) and EGFP was used as a negative control (supplemental Fig. $2 \mathrm{~A}$, available at www.jneurosci.org as supplemental material). Suppression of Noxl gene expression was shown by the specific reduction in the level of Noxl transcripts in WT or Nox2-KO microglial cultures transduced with shNox1 (supplemental Fig. 2B, available at www.jneurosci.org as supplemental material). Lentiviral transduction did not affect microglial cell morphologies examined by phase contrast microscopy (data not shown). Consistent with the detection of $\mathrm{p} 22^{\text {phox }}$ stabilized through association with Nox proteins, staining of [Nox1p22 $\left.{ }^{\text {phox }}\right]$ heterodimers was strongly reduced in shNox1/EGFPtransduced Nox2-KO microglia but not in shCtrl-transduced cells (Fig. 2C). In WT microglia, [Nox2-p22 $\left.{ }^{\text {phox }}\right]$ dimers were prominent, preventing clear observation of the loss of $\mathrm{p} 22^{\text {phox }}$ after silencing of the Nox1 gene. It is currently thought that p $22^{\text {phox }}$ mRNA is not limiting for $\mathrm{p} 22^{\text {phox }}$ protein expression but that the $\mathrm{p} 22^{\text {phox }}$ monomer is rapidly degraded in the cytosolic proteasome when $\left[\right.$ Nox-p22 $\left.{ }^{\text {phox }}\right]$ heterodimers are not formed (DeLeo et al., 2000; Ambasta et al., 2004; Bedard and Krause, 2007). As expected from the loss of the $\mathrm{p} 22^{\text {phox }}$ resulting from increased degradation of the protein, the levels of p $22^{\text {phox }}$ transcripts were not reduced in shNox1-transduced microglia (supplemental Fig. $2 B$, available at www. jneurosci.org as supplemental material).

Catalytic activity of Nox1 is stimulated by zymosan and LPS in microglia Phagocytosis of serum-opsonized zymosan is a potent stimulator of the Nox2 phagocyte oxidase (Sankarapandi et al., 1998). However the redistribution of p $22^{\text {phox }}$ to the phagosomal membranes of Nox2-KO microglia suggested that Nox1 is also activated by zymosan phagocytosis and generates $\mathrm{O}_{2}{ }^{--}$in the phagosome lumen. To detect $\mathrm{O}_{2}{ }^{--}$generated by phagosomal membranes in Nox2-KO microglia, we used the $\mathrm{O}_{2}{ }^{--}$-mediated reduction of NBT to insoluble formazan, which labels intracellular sources of $\mathrm{O}_{2}{ }^{--}$(Serrander et al., 2007). Exposure of engulfing Nox2-KO microglia to NBT triggered formation of a dark precipitate which closely surrounded engulfed zymosan particles (Fig. 3A) and matched with the [Nox1p22 $\left.{ }^{\text {phox }}\right]$ heteromers in phagosomal membranes (Fig. $2 \mathrm{~B}$ ). To show that the phagosomal $\mathrm{O}_{2}^{--}$was indeed produced by Nox1, engulfing cells were exposed to the flavoprotein inhibitor diphenylene iodonium (DPI), a compound that directly blocks the catalytic activity of Nox proteins (Doussiere et al., 1999). Cell treatment with DPI $\left(\begin{array}{ll}1 & \mu \mathrm{M}\end{array}\right)$ prevented phagosome staining in Nox2-KO engulfing cells, although it did not block microglial phagocytosis of zymosan (Fig. 3A).

Intracellular production of $\mathrm{O}_{2}^{--}$in engulfing microglia was quantified at the cellular level by the $\mathrm{O}_{2}{ }^{--}$-mediated oxidation of hydroethidine (Bindokas et al., 1996), which results in the formation of fluorescent products that bind to DNA. Engulfment of zymosan particles by WT microglia triggered a massive production of $\mathrm{O}_{2}^{--}$in the phagosome lumen as shown by the strong fluorescence of oxidized hydroethidine in zymosan DNA counterstained with Hoechst dye (Fig. 3B). Forty-five minutes after incorporation of zymosan in the WT microglial cultures, a 15fold increase in hydroethidine oxidation was observed in cells that had engulfed at least 10 zymosan particles, compared with nonengulfing (control) microglia (Fig. 4A,B). In Nox2-KO cells, there was only a fivefold increase in hydroethidine oxidation. Cell treatment with DPI fully abrogated zymosan-stimulated production of $\mathrm{O}_{2}{ }^{--}$in both WT and Nox2-KO microglia, indicating that the phagosomal $\mathrm{O}_{2}{ }^{--}$was indeed produced by Nox1 and Nox2 (Fig. $4 A, B$ ).

LPS has been reported to activate NADPH oxidase in different types of phagocytes, including microglia (Qin et al., 2004; Miletic et al., 2007). To investigate the role of Nox1 and Nox2, we assessed $\mathrm{O}_{2}{ }^{--}$production in LPS-stimulated WT and Nox2-KO 
A
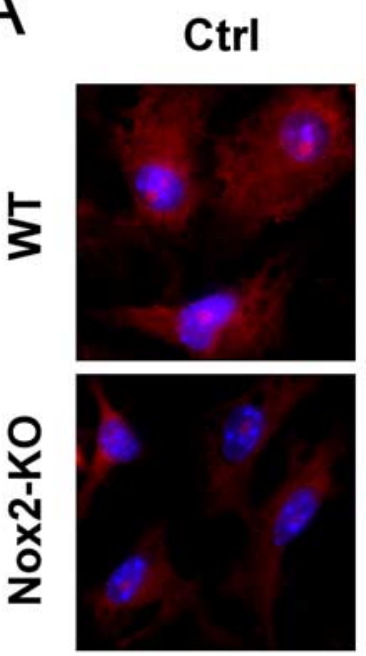

B

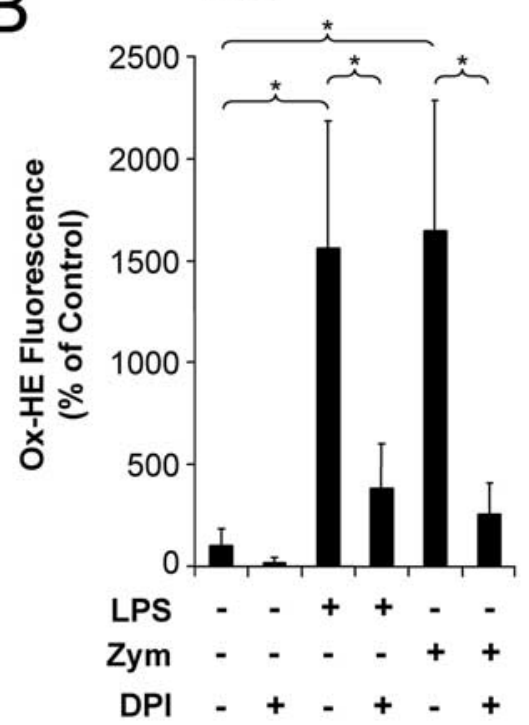

Zym
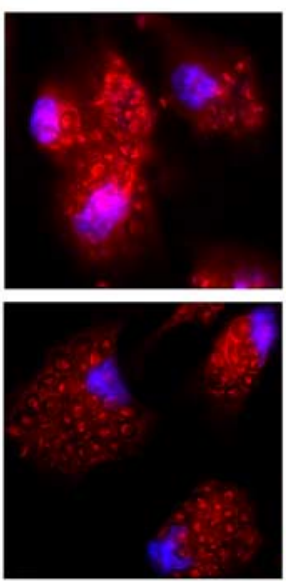
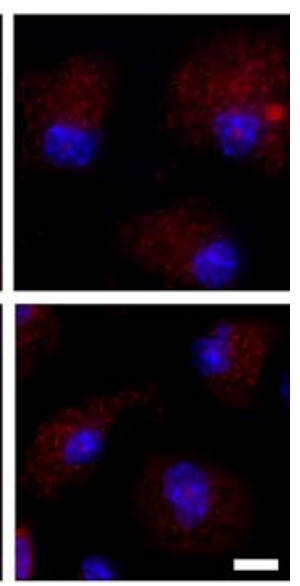

$\square$ Nox2-KO

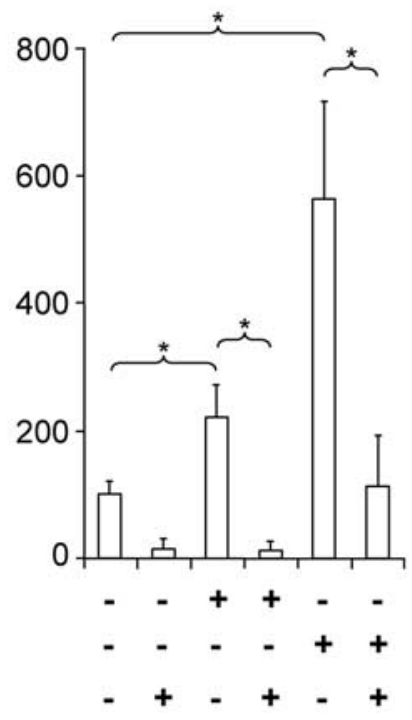

Zym + DPI

C

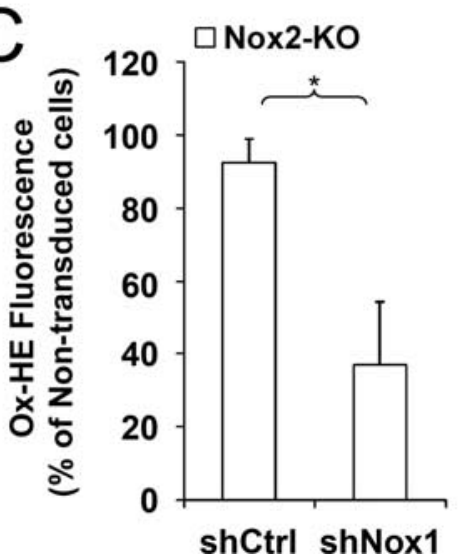

Figure 4. Contributions of Nox1 and Nox2 to intracellular $\mathrm{O}_{2}^{-{ }^{--}}$levels in activated microglia. $\boldsymbol{A}, \boldsymbol{B}$, Cultured WT and Nox2-KO microglia were incubated for 45 min with cell-permeant hydroethidine in the absence (Ctrl) or the presence of $L P S$ or zymosan and with or without DPI before assessment of hydroethidine oxidation. $A$, Red fluorescence resulting of hydroethidine oxidation in cells that have ingested zymosan. Strongly enhanced fluorescence is localized in phagosomes containing zymosan in WT or Nox2-K0 cells. Fluorescence is strongly reduced when cells are incubated with DPI. Hoechst 33342 dye counterstaining (blue) reveals cell nuclei. Scale bar, $10 \mu \mathrm{m}$. B, Levels of oxidized hydroethidine (0x-HE) were determined by fluorescence intensity normalized to the number of cells and are expressed as the percentage of the mean control value determined in cultures without LPS, zymosan or DPI. In zymosan-treated cultures, $0 x$-HE levels were determined in cells containing at least 10 zymosan particles. Data are the mean \pm SD of two (Nox2-K0 cells) or three (WT cells) separate experiments with 5-15 determinations in sister wells microglia. LPS (100 ng/ml) induced a 15fold increase of hydroethidine oxidation throughout the cytoplasm of WT microglia, similar to levels reached in zymosanstimulated cells, but only a twofold increase in Nox2-KO microglia (Fig. 4B). This shows that Nox2 plays a prominent role in LPS-triggered microglial generation of $\mathrm{O}_{2}{ }^{--}$. Consistent with the activation of Nox2, DPI strongly suppressed $\mathrm{O}_{2}{ }^{--}$production in LPS-stimulated WT microglia. DPI also fully prevented LPSinduction of $\mathrm{O}_{2}{ }^{-}$in Nox2-KO microglia, indicating that Nox1 is also implicated in LPS-stimulated $\mathrm{O}_{2}{ }^{-}$production (Fig. $4 A, B)$.

Because Nox 2 produced a high level of $\mathrm{O}_{2}{ }^{-}$, the decrease in Nox1-derived $\mathrm{O}_{2}{ }^{\cdot-}$ after silencing of the Nox 1 gene in WT microglial is difficult to visualize. However, to further confirm the role of Nox1 in LPSinduced $\mathrm{O}_{2}{ }^{-}$production, Nox2-KO microglial cultures were transduced with lentiviral vectors shNoxl/EGFP or shCtrl/ EGFP before LPS stimulation and assessment of hydroethidine oxidation. To allow comparison of EGFP-expressing cells and nontransduced (EGFP-negative) cells in the same culture wells, $\mathrm{O}_{2}{ }^{-}$production was measured in cultures in which the mean proportions of shNox1- or shCtrl-transduced cells were close to $40 \%$. Hydroethidine oxidation was $>60 \%$ lower in shNoxl-transduced cell than in nontransduced cells, whereas shCtrltransduction had no significant effect on the level of hydroethidine oxidation (Fig. $4 C)$. LPS treatments and zymosan phagocytosis therefore both activate Noxl and Nox2 in microglia. However, it cannot be ruled out that the level of Nox1 protein and/or the amount of $\mathrm{O}_{2}{ }^{--}$produced by Nox1 might differ in WT and in Nox2-KO microglia, even though assessment of Nox1 mRNA levels did not reveal a compensatory upregulation of the Noxl gene in Nox2-KO microglia (supplemental Fig. 1, available at www.jneurosci.org as supplemental material).

$\leftarrow$

per experiment. The asterisk indicates significant differences ( $p<0.01$; one-way ANOVA followed by Student-NewmanKeuls multiple-comparisons test). C, Nox2-K0 cells were transduced with lentiviral shNox1 or shCtrl before incubation with hydroethidine in the presence of LPS. Levels of oxidized hydroethidine (0x-HE) were determined in transduced (EGFP-stained) and nontransduced cells and are expressed as the percentage of the mean value of nontransduced cells in each well. A total of 600 cells were assessed in each well. The mean proportion of assessed cells expressing EGFP was 38\%. Data are mean \pm SD from six determinations in sister wells $\left({ }^{*} p<0.001\right.$ in Welch's $t$ test). 
A

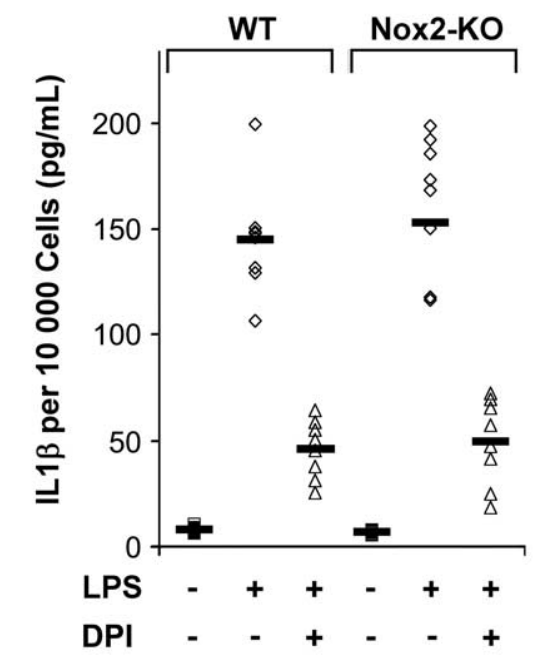

B

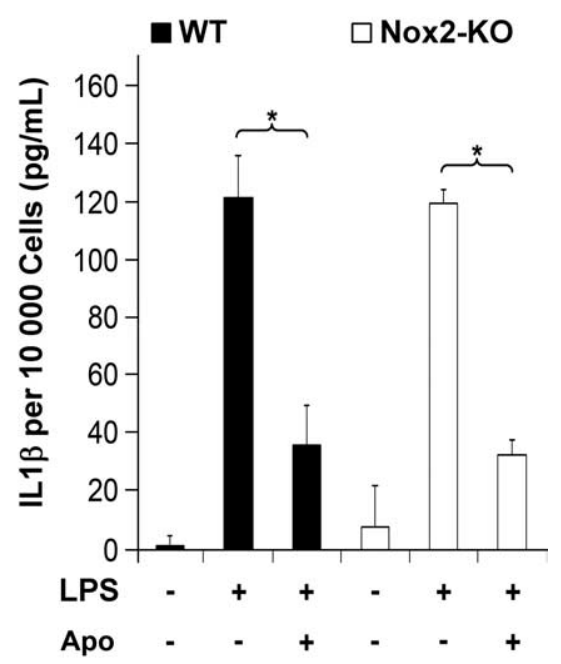

$\mathcal{C}$

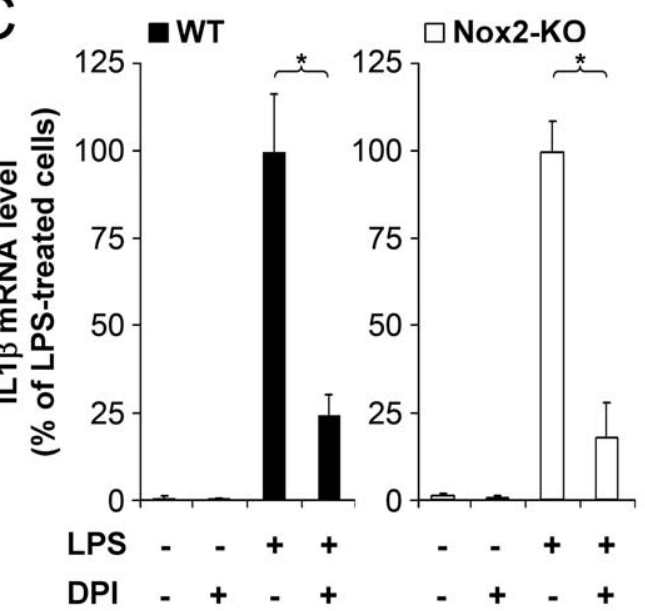

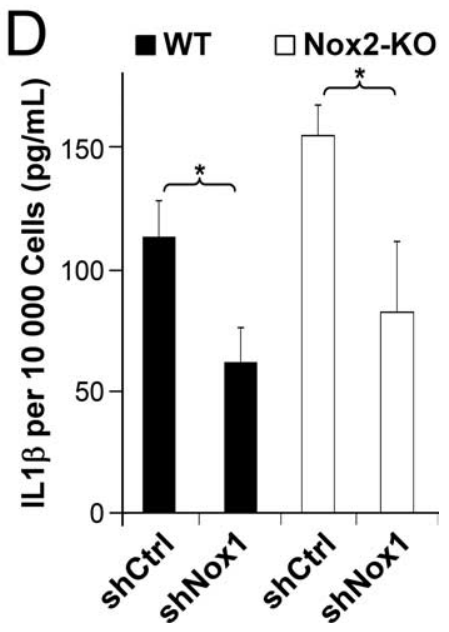

Figure 5. Nox1 promotes microglial production of IL-1 $\beta . A, B$, ELISA determination of IL-1 $\beta$ levels in the medium of WT or Nox2-K0 microglial cultures treated or not with indicated reagents for $16 \mathrm{~h}$. $A$, Dots represent mean values in eight WT and eight Nox2-KO independent experiments ( $5-6$ determinations in sister wells per experiment). Bold lines indicate the mean value calculated from the means of the independent experiments. $\boldsymbol{B}$, Apocynin (Apo) was used. For each genotype, data are mean $\pm S D$ of six determinations in sister wells from a representative experiment $\left({ }^{*} p<0.001\right.$, SNK test). C, Real-time PCR determination of IL-1 $\beta$ mRNA levels in cultures treated for $150 \mathrm{~min}$. IL-1 $\beta$ levels are expressed as percentage of the mean value determined in LPS-treated cultures. Data are the mean \pm SD of three independent experiments with two determinations in sister wells per experiment $\left({ }^{*} p<0.001\right)$. D, Microglial cultures transduced with lentiviral shNox1 or shCtrl were treated with LPS for $16 \mathrm{~h}$ before ELISA detection of IL-1 $\beta$. For each genotype, data are mean $\pm S D$ of six determinations in sister wells from a representative experiment ( ${ }^{*} p<0.001$, Student's $t$ test). Mean percentage of transduced microglia exceeds $85 \%$ for each genotype (WT or Nox2-K0).

Nox1 promotes microglial production of IL-1 $\beta$ and NO.

Recent studies have shown that Nox-derived ROS participate in redox modulation of LPS-triggered cell signaling in microglia (Pawate et al., 2004). To determine the respective roles of Nox2 and Noxl, we examined IL- $1 \beta$ and NO- production in WT and Nox2-KO. Microglial cultures were stimulated with LPS at a final concentration of $100 \mathrm{ng} / \mathrm{ml}$ that did not alter cell survival over a $16 \mathrm{~h}$ period of treatment (supplemental Fig. 3, available at www. jneurosci.org as supplemental material). We also verified by RTPCR that in LPS-treated microglia, Nox1 (WT and Nox2-KO cells) and Nox2 (WT cells) remained expressed, whereas Nox3, Nox4, or Duox transcripts were not induced (data not shown).

LPS strongly stimulated the release of IL- $1 \beta$ by WT and Nox2-KO microglia. The mean levels of IL- $1 \beta$ secretion and their range were very similar in WT and in Nox2-KO microglia treated with LPS, indicating that Nox2 is not necessary for LPS-triggered secretion of IL$1 \beta$. (Fig. 5A) (no significant differences in nonparametric Kruskal-Wallis multiplecomparisons test followed by Dunn's test).

The Nox inhibitor DPI reduced IL- $1 \beta$ secretion by $65 \%$ on average in WT and Nox2-KO microglia cultures stimulated with LPS (significant difference between untreated and DPI-treated cultures in each genotype; Dunn's test, $p<0.05)$. As for untreated cultures, there was no significant difference in IL- $1 \beta$ secretion between WT and Nox2-KO microglia treated with DPI (Fig. 5A). DPI also reduced the levels of IL- $1 \beta$ transcripts in WT and Nox2-KO microglia by $>80 \%$, assessed by real-time PCR after 150 min of LPS treatment, when the effect reaches a plateau (Fig. 5C). DPI is a potent blocker of Nox proteins but can also directly inhibit other flavoenzymes (Stuehr et al., 1991; Tew, 1993) that might possibly impact on microglial production of IL- $1 \beta$. We therefore assessed the effects of apocynin, a compound that inhibits assembly of the phagocyte NADPH oxidase, and has been used to block Nox activities in different cell types, including microglia (Stolk et al., 1994; Mander et al., 2006). Similar to the effect of DPI, apocynin at the optimal concentration of $1 \mathrm{~mm}$ reduced IL- $1 \beta$ secretion by $>60 \%$ in both WT and Nox2-KO microglia (Fig. 5B). Altogether, microglial treatment with NADPH oxidase inhibitors provides evidence that Nox1 activity promotes the LPS-induced IL- $1 \beta$ secretion at the transcriptional level or enhances the stability of IL- $1 \beta$ transcript.

To confirm the role of Noxl in the induction of IL- $1 \beta$, WT and Nox2-KO microglial cultures were transduced with the lentiviral vectors shNox 1 and shCtrl, then stimulated with LPS for $16 \mathrm{~h}$ before assessment of IL- $1 \beta$. Figure $5 D$ shows the results obtained in cultures in which the mean percentage of transduced microglia was $>85 \%$ and did not differ significantly between shNox1- and shCtrl-treated cells. The mean IL-1 $\beta$ levels in WT and Nox2-KO microglia was at least $45 \%$ lower in shNox1than in shCtrl-transduced cultures, confirming that Nox1 promotes the production of IL- $1 \beta$ by microglia stimulated with LPS. Noteworthily, the magnitude of DPI-, apocynin-, or shNox1inhibitory effects were very similar in WT and Nox2-KO microglia (Fig. 5), indicating that the loss of Nox2 does not significantly alter Nox1 regulation of IL-1 $\beta$.

In contrast to IL- $1 \beta$, the mean LPS-induced NO- production assessed by nitrite levels was 50\% lower in Nox2-KO microglia than in WT cells (Fig. 6A) (Dunn's test, $p<0.05$ ), indicating that Nox2 is implicated. Treatment of microglia with the NO synthase inhibitor $\mathrm{N}$-monomethyl-L-arginine $(500 \mu \mathrm{M})$ prevented NO production but did not reduce LPS-triggered IL- $1 \beta$ secretion (data not shown), confirming that Nox2 regulation of NO• (Fig. 

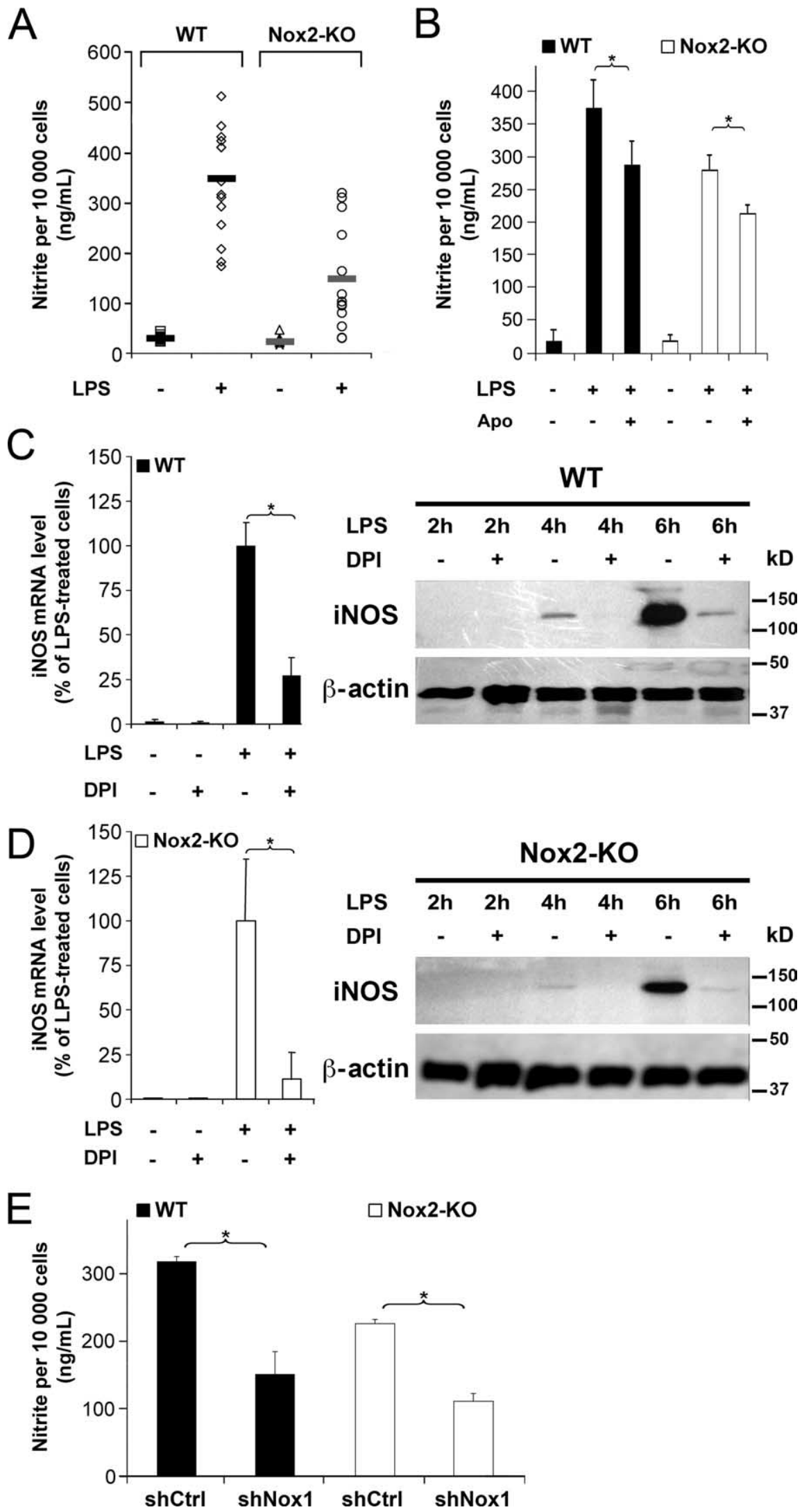

Figure 6. Both Nox1 and Nox2 promote microglial production of $\mathrm{NO} \cdot A, B$, Cell production of $\mathrm{NO} \cdot$ was determined by colorimetric measurement of nitrite levels in the medium of WT or Nox2-K0 microglial cultures treated or not with LPS or LPS and apocynin for $16 \mathrm{~h}$. $\boldsymbol{A}$, Dots represent mean values in 15 WT and 13 Nox2-K0 independent experiments (5- 6 determinations in sister wells per experiment). Bold lines indicate the mean value calculated from the means of the independent experiments. $\boldsymbol{B}$, For each genotype, data are mean \pm SD of six determinations in sister wells from a representative experiment $\left({ }^{*} p<0.01\right.$, SNK test). C, D, Real-time PCR determination of iNOS mRNA levels and Western blot detection of INOS protein in WT (C) or Nox2-KO (D)
$6 A)$ can occur without an effect on IL-1 $\beta$ production (Fig. 5A). Apocynin significantly reduced $\mathrm{NO}$ - production in LPSstimulated WT and Nox2-KO microglia (Fig. 6 B). Although quite low $(20-30 \%$ reduction in nitrite levels according to the experiments), this inhibitory effect suggested that not only Nox2 but also Nox1 promoted microglial production of $\mathrm{NO}$. Because LPS triggers microglial NO• production through induction of the gene encoding inducible NO synthase (iNOS) (Fiebich et al., 1998), a flavoprotein enzyme the activity of which may be directly blocked by DPI (Stuehr et al., 1991), we could not use DPI to determine directly whether Noxl is also implicated in $\mathrm{NO}$. production. We therefore compared the effect of DPI on iNOS mRNA and iNOS protein levels in LPS stimulated WT and Nox2-KO microglia. DPI strongly reduced iNOS mRNA and protein levels in both WT and Nox2-KO microglia (Fig. 6C,D). Levels of INOS protein after $6 \mathrm{~h}$ exposures to LPS were estimated by densitometric analysis of iNOS and $\beta$-actin bands in Western blot experiments (Fig. 6). DPI reduced the mean iNOS/ $\beta$-actin ratio by $>80 \%$ in both WT and in NOX2-KO microglia (iNOS/ $\beta$-actin ratio in WT microglia: $7 \pm 4 \%$ in DPI-treated cells, $100 \pm$ $28 \%$ in untreated cells; NOX2-KO microglia: $15 \pm 6 \%$ in DPI-treated cells, $100 \pm$ $38 \%$ in untreated cells; values are expressed relative to the mean ratio in untreated cells set as 100\% for each genotype; data are mean $\pm \mathrm{SD}$ from three independent experiments; differences between DPI-treated and untreated cells are significant ( $p<0.05$ in Welch's $t$ test). Although flavoenzymes blocked by DPI are not limited to Nox proteins, the microglial responses to DPI and apocynin treatments support the contention that Nox1 pro-

\footnotetext{
$\leftarrow$

microglial cultures treated or not with LPS and/or DPI. iNOS mRNA levels were assessed in cells exposed 150 min to LPS with or without DPI and are expressed as percentage of the mean value in LPS-treated cultures; data are mean \pm SD of three independent experiments with two determinations in sister wells per experiment. Images show Western blot detections of iNOS and $\beta$-actin in total protein extracts $(7.5 \mu \mathrm{g} /$ lane) of microglial cultures treated for $2-6 \mathrm{~h}$ with LPS in the absence or the presence of DPI. $\boldsymbol{E}$, Microglial cultures transduced with lentiviral shNox1 or shCtrl were treated with LPS for $16 \mathrm{~h}$ before measurement of nitrite levels in the culture medium. For each genotype, nitrite levels are expressed as percentage of the mean value in shctrl-transduced cultures. For each genotype (WT or Nox2-K0), data are mean \pm SD of six determinations in sister wells from a representative experiment ${ }^{*} p<0.001$, Student's $t$ test). Mean percentage of transduced microglia exceeds $85 \%$ for each genotype (WT or Nox2-KO).
} 
Table 2. Nox1-K0 microglia stimulated with LPS produce less N0 than WT cells

\begin{tabular}{llll}
\hline & \multicolumn{2}{l}{ Nitrite $(\mathrm{ng} / \mathrm{ml}$ per 10,000 cells) } & \\
\cline { 2 - 3 } Exp number & WT & Nox1-K0 & Percentage difference \\
\hline 1 & $624 \pm 46$ & $275 \pm 32$ & $-56^{* *}$ \\
2 & $429 \pm 18$ & $132 \pm 7$ & $-69^{* *}$ \\
3 & $409 \pm 31$ & $110 \pm 12$ & $-73^{* *}$ \\
4 & $365 \pm 37$ & $282 \pm 19$ & $-23^{*}$ \\
\hline
\end{tabular}

In each experiment (Exp), both WT and Nox1-K0 microglia were treated with LPS for $16 \mathrm{~h}$ before assessment of nitrite levels. Data are mean $\pm S D$ of six determinations in sister wells. Asterisks indicate significant differences between WT and Nox1-KO cells $\left({ }^{*} p<0.01,{ }^{* *} p<0.001\right.$, Student's $t$ test).

motes iNOS expression and $\mathrm{NO} \cdot$ production, at least in Nox2-KO microglia. Furthermore, silencing of Nox1 gene reduced the production of NO by at least $50 \%$ in both WT and Nox2-KO microglial stimulated with LPS (Fig. $6 E$ ), showing that Nox1 promotes microglial production of $\mathrm{NO} \cdot$ whether or not the cells express functional Nox2. To assess whether the Nox2-promoted NOproduction can eventually compensate for a chronic deficiency in Nox1, we compared NO production in LPS-treated microglia derived from WT or Nox1-KO mice. Despite the variation in absolute nitrite levels in independent experiments, $\mathrm{NO} \cdot$ production was consistently lower (23-73\%) in Nox1-KO microglia than in WT cells (Table 2). Together with the reduced NO• production in Nox2-KO cells (Fig. 6A), our data indicate that both Nox 1 and Nox 2 are required to optimize microglial production of $\mathrm{NO}$.

\section{Nox1 deletion reduces tyrosine nitration and synapsin loss induced by intracerebral injection of LPS}

Coactivation of NADPH oxidase and iNOS promote a reaction between $\mathrm{O}_{2}{ }^{--}$and $\mathrm{NO}$, which gives rise to highly pro-oxidant peroxynitrite $\left(\mathrm{ONOO}^{-}\right.$) (Szabó et al., 2007). This compound triggers the formation of nitrotyrosine residues (Ntyr), which provides a tissue marker for reactive nitrogen-related tissue damage (Torreilles et al., 1999).

The preceding experiments show that Nox1 activity generates $\mathrm{O}_{2}{ }^{--}$and promotes $\mathrm{NO} \cdot$ production in purified microglia. To investigate in vivo whether Nox1 promotes the intracerebral formation of deleterious nitrogen species, we injected LPS unilaterally into the striatum of adult WT or Nox1-KO mice from the same litter and we examined microglial activation and Ntyr production by immunohistochemistry in the brains fixed $4 \mathrm{~d}$ later. LPS strongly induced a microglial activation shown by the accumulation of amoeboid cells, especially in the vicinity of the needle track in the striatum of WT or Nox1-KO mice. High levels of Ntyr were observed at the level of the microglial reaction, but less in Nox1-KO than in WT mice. The highest levels of Ntyr were found in microglial cell bodies (Fig. 7). Ntyr was not detectable in uninjected brains or in the striatum contralateral to the injection site of WT or Nox1-KO mice. Ntyr and microglial activation were quantified in the cortical area surrounding the needle track, in which the density of activated microglia was lower than in the striatal injection site; thus individualized cells could be counted. The density of microglial cells determined by counts in microscopic fields (see methods) did not differ significantly between WT (101 \pm 24 cells per field) and Nox1-KO mice (92 \pm 37 cells per field), whereas the proportion of microglial cells stained with anti-Ntyr dropped from $91 \pm 9 \%$ in WT brain to $47 \pm 16 \%$ in Nox1-KO mice (data are mean \pm SD from 5 animals of each genotype). As in the in vitro experiments, these results indicate that Nox1 promotes the formation of aggressive reactive nitrogen intermediates in activated microglia.

In previous studies, LPS caused neuronal death when injected in the striatum of rats and gerbils but not mice, as indicated by silver or cresyl violet staining (Zito et al., 2001; Choi et al., 2007). In agreement with these observations, we detected very few degenerating cells by TUNEL staining of LPS-injected striatum in WT or Nox1-KO mice (data not shown). However, to further investigate the role of Noxl in inflammation-triggered tissue damage, we looked for synapse alterations in WT and Nox1-KO mice injected with LPS by immunolabeling of synapsins, a family of presynaptic proteins linking synaptic vesicles to cytoskeleton proteins (Ferreira and Rapoport, 2002). Synapsin immunoreactivity was decreased, compared with the contralateral striatum, in the striatal region in which LPS induced both microglial and astroglial reactions (Fig. 8A,B). Quantification in the striatum $300 \mu \mathrm{M}$ below the injection site showed a $40 \%$ decrease in synapsin immunoreactivity compared with the contralateral striatum (Fig. $8 C, D$ ). In striking contrast with the intensity of microglial and astroglial reactions, which reached the level of those observed in WT (Fig. $8 A, B$ ), there was no loss of synapsin in the striata of LPS-injected Nox1-KO mice (Fig. 8D).

\section{Discussion}

Previous studies have shown that microglia express the full set of specific proteins that compose the phagocyte oxidase (Nox2, $\mathrm{p} 22^{\text {phox }}, \mathrm{p} 47^{\text {phox }}, \mathrm{p} 40^{\text {phox }}, \mathrm{p} 67^{\text {phox }}$, and Rac) (Bianca et al., 1999) and release $\mathrm{O}_{2}{ }^{--}$or $\mathrm{O}_{2}{ }^{--}$-derived hydrogen peroxide when exposed to LPS, opsonized zymosan, or aggregated proteins that accumulate in the brain during neurodegenerative diseases (Sankarapandi et al., 1998; Zhang et al., 2005; B. Qin et al., 2006; Wilkinson et al., 2006). We have shown here, for the first time, that in addition to the phagocyte oxidase, microglia express the genes encoding all the components (Nox1, p22 ${ }^{\text {phox }}$, NOXO1, NOXA1, and rac) of a nonphagocyte NADPH oxidase. This finding implicated that characterization of Nox functions in microglia required analyses of single and double Nox deficiencies. In these studies, we used pharmacological inactivation of Nox activity or specific shNox1-mediated gene silencing in combination with Nox2-KO mice to overcome the difficulty of producing double $\mathrm{KO}$ animals by cross-breeding given the localization of both the Nox1 and Nox2 genes on chromosome X.

Our experiments have shown that activated Noxl catalyzes the formation of $\mathrm{O}_{2}{ }^{-}$in response to engulfment of yeast particles and LPS stimulation. The $\mathrm{O}_{2}{ }^{--}$generated by Nox1 favors microglial production of IL- $1 \beta$, NO• and highly deleterious $\mathrm{ONOO}^{-}$ triggered by LPS, and causes synaptic damage in a LPS-triggered neuroinflammatory lesion.

The distribution of $\mathrm{p} 22^{\text {phox }}$ in WT and Nox2-KO microglia indicates that $\left[\right.$ Nox $\left.1-\mathrm{p} 22^{\text {phox }}\right]$ dimers are restricted to intracellular vesicles, some of which are lysosomes, whereas part of the [Nox2-p22 ${ }^{\text {phox }}$ flavocytochromes are located in the plasma membrane. Because $\mathrm{O}_{2}{ }^{--}$diffuses poorly through phospholipid bilayers, this result suggests that extracellular release of Nox1derived $\mathrm{O}_{2}{ }^{--}$is very limited. Accordingly, formation of extracellular $\mathrm{O}_{2}{ }^{--}$was not detected in LPS-stimulated microglial cultures from Nox2-KO mice (Qin et al., 2004). However, the detection of $\mathrm{O}_{2}{ }^{--}$and $\mathrm{p} 22^{\text {phox }}$ in microglia that have engulfed yeast particles shows that phagocytosis triggers redistribution of [Nox1$\mathrm{p} 22^{\text {phox }}$ ] dimers to phagosome membranes and that Nox1 significantly contributes to $\mathrm{O}_{2}{ }^{-}$- accumulation in phagosomes. Phagosomal Nox1 most likely originates from the fusions of lysosomes and phagosomes, whereas phagosomal Nox 2 might derive at least in part from the plasma membrane incorporated in the primary phagosome.

Phagocyte oxidase is primarily involved in the immune de- 
fense against microorganisms ingested by circulating or tissue phagocytes. The $\mathrm{O}_{2}{ }^{-}$ produced in phagolysosomes indirectly activates proteases (Reeves et al., 2002) and gives rise to halide derivatives (Nauseef, 2007), which eventually destroy ingested bacteria or fungi. It is therefore possible that microglial Nox1 contributes to an immune defense against microorganisms that threaten the CNS (Rock et al., 2004). The cytotoxic activity of phagosomal $\mathrm{O}_{2}{ }^{--}$also participates in normal development, where engulfing microglia cause neuronal apoptosis (Marín-Teva et al., 2004; Wakselman et al., 2008). Our study shows that Nox1, expressed in microglia in the developing brain, might play a key role in this mechanism of neuronal death.

In neuroinflammatory states, activated microglia may be detrimental for neural cells. LPS-activated microglia kill neurons or oligodendrocyte progenitors directly in cell culture via microglial production of IL- $1 \beta$, NO; , or Nox2-derived ROS (Ma et al., 2002; Li et al., 2005). These same compounds have also been implicated in the neural tissue damage induced by injection of LPS in rodent brain (Iravani et al., 2002; Cai et al., 2003; Arai et al., 2004; Qin et al., 2004). We now show that Nox1 activity markedly promotes microglial production of NO and IL- $1 \beta$ triggered by LPS. We also provide evidence for the implication of microglial Nox1 in the generation of neurotoxic $\mathrm{ONOO}^{-}$and synapse loss after intracerebral injection of LPS.

Interestingly, Nox1, but not Nox2, was implicated in microglial LPS-stimulated IL- $1 \beta$ production, whereas both oxidases upregulated microglial $\mathrm{O}_{2}{ }^{--}$and $\mathrm{NO} \cdot$ production in response to LPS. Despite this common effect on NO production, the functions of Nox1 and Nox2 were not redundant, because microglial production of $\mathrm{NO}$. was reduced by inactivating either the Nox2 or Noxl gene. Furthermore, inhibition of Nox1 expression or activity in Nox2-KO microglia showed that $\mathrm{O}_{2}{ }^{--}$generated by Nox1 are sufficient to promote iNOS gene expression and NO. production in the absence of Nox 2 activity. It was previously shown with Nox inhibitors and ROS scavengers that Nox was implicated in LPS-triggered rat microglial production of $\mathrm{NO}$ (Pawate et al., 2004). We verified that purified rat primary microglia, like mouse cells, express Nox1 and Nox2 (data not shown). Therefore, both of the oxidases probably regulate NO production in rat microglia. However, a recent study suggests that cultured rat microglia express Nox4 (Harrigan et al., 2008), unlike the mouse microglia investigated here. LPS stimulation of Nox1expressing Nox2-KO microglia was reduced by apocynin, a compound thought to act by blocking translocation of cytosolic p $47^{\text {phox }}$ to [Nox-p22 ${ }^{\text {phox }}$ ] dimers (Stolk et al., 1994). This suggests that in addition to NOXO1/NOXA1-regulation, microglial Nox1 may also be activated through $\mathrm{p} 47^{\mathrm{phox}} / \mathrm{p} 67^{\text {phox }}$ binding, as documented in other cells (Bedard and Krause, 2007).

LPS signals through the toll-like receptor 4 (TLR4), which promotes LPS-triggered microglial neurotoxicity (Lehnardt et al., 2003), although this receptor is not required for LPS activation of microglial Nox2 (Qin et al., 2005). TLR4 activates multi- ple intracellular signaling pathways leading to transcription of genes, such as $i N O S$ and $I L-1 \beta$ (O'Neill and Bowie, 2007). Nox1dependent increase of IL- $1 \beta$ and iNOS transcripts might result from the oxidative modulation of a variety of redox-sensitive signaling proteins, such as MAP kinase family members, Tyrosine protein phosphatases or transcription factors such as $\mathrm{NF} \kappa \mathrm{B}$ or AP1 (Dröge, 2002; Veal et al., 2007). Although both Nox 1 and Nox 2 were activated by LPS, differential effects of Nox proteins in microglial expression of $I L-1 \beta$ and $i N O S$ genes suggest that microglial Nox1 and Nox2 target different redoxsensitive signaling compounds, possibly because of differences in the subcellular distributions of catalytically active Nox and LPSsignaling components (Hunter, 2000). Consistent with this hypothesis, increasing evidence indicates that intracellular ROS signaling is spatially restricted by the compartmentalization of peroxide-decomposing enzymes such as catalase, glutathione peroxidase, and thioredoxin peroxidase (Veal et al., 2007).

$\mathrm{O}_{2}{ }^{--}$and $\mathrm{NO} \cdot$ combine at diffusion-limited rates to form highly reactive $\mathrm{ONOO}^{-}$that has been implicated in the death of cultured neurons or oligodendrocyte progenitors exposed to LPS-activated microglia (Xie et al., 2002; Li et al., 2005). Tyrosine nitration, a marker of $\mathrm{ONOO}^{-}$activity, has been correlated with tissue damages in human neuropathologies such as multiple sclerosis, ALS, and Parkinson's and Alzheimer's diseases, as well as in animal models of these diseases, including LPS-triggered neuroinflammation (Torreilles et al., 1999; Hill et al., 2004; TomásCamardiel et al., 2004). Although Nox2 may contribute to $\mathrm{ONOO}^{-}$formation in part through increased microglial production of $\mathrm{NO} \cdot(\mathrm{Li}$ et al., 2005; this study), we provide three lines of evidence supporting the hypothesis that microglial Nox1 plays an important role in the generation of neurotoxic $\mathrm{ONOO}^{-}$. (1) Nox1 promotes LPS-triggered expression of 
A

Iba1

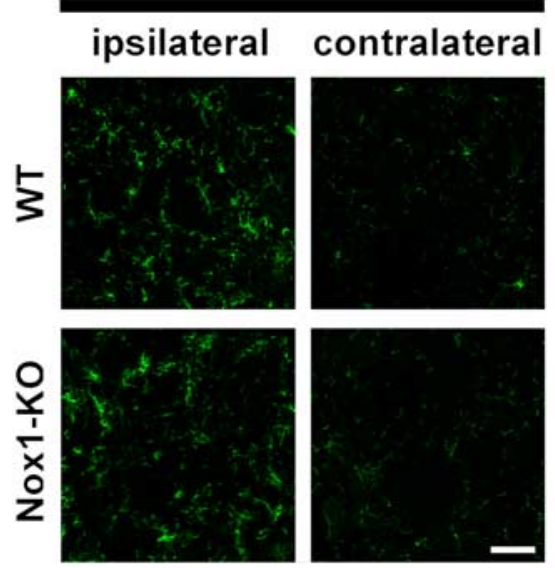

C
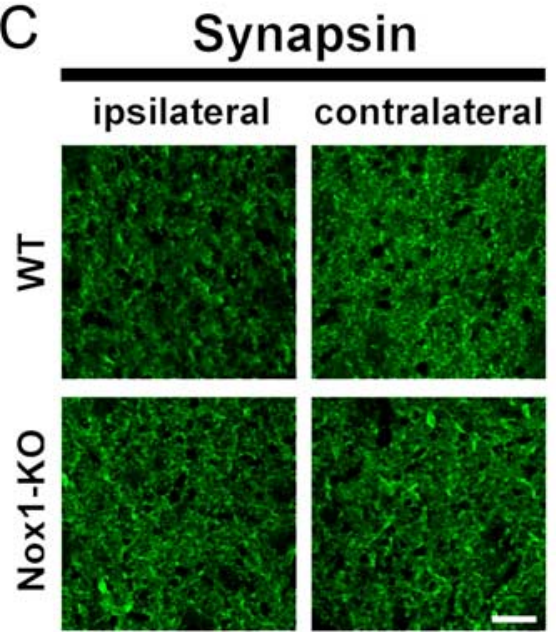

B

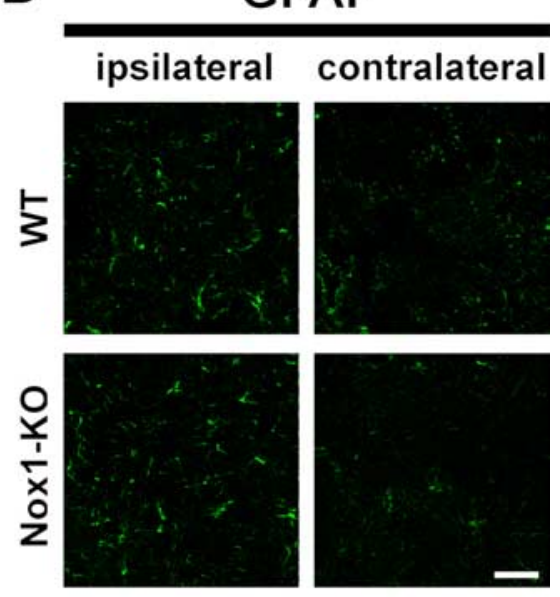

D

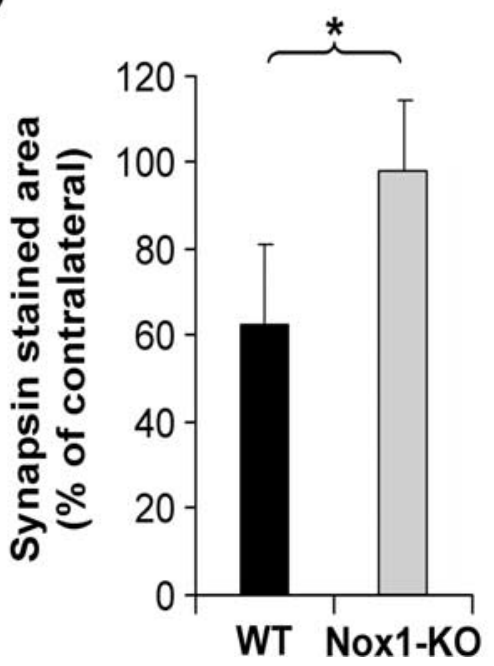

Figure 8. Nox1 deletion prevents loss of synapsin in LPS-injected mouse striatum. $A-C$, Striatal fields from WT and Nox1-K0 mice stained with rabbit polyclonal anti-lba1 (microglial staining) $(\boldsymbol{A})$, anti-GFAP (astrocyte staining) $(\boldsymbol{B})$, or anti-synapsin $(\boldsymbol{C})$ ipsilateral or contralateral to the lesional tract and localized $300 \mu \mathrm{m}$ ventral to the injection site. Scale bars, $50 \mu \mathrm{m}$. D, Data represent the area of synapsin staining in ipsilateral striata normalized to the contralateral region for each genotype (mean $\pm S D$ from 5 animals of each genotype, ${ }^{*} p<0.01$, Student's $t$ test).

iNOS and NO production in microglia. (2) Nox1 produces $\mathrm{O}_{2}{ }^{-}$, which may react with $\mathrm{NO} \cdot$ formed in microglia. (3) Striatal injection of LPS was followed by a much larger increase in Ntyr formation in WT than in Nox1-KO mice. Consistent with the cell autonomous regulation of microglial iNOS by Nox1, the increase in tyrosine nitration clearly occurred within activated microglia.

Cell death is very limited in LPS-injected mouse striatum. However, the extensive formation of Ntyr in microglia suggests that activated microglia may cause oxidative damage to neighboring neurons through the diffusion of $\mathrm{ONOO}^{-}$, which is known to induce structural and functional alterations of synapse components (Zaidi and Michaelis, 1999). Loss of synaptic proteins associated with microglial activation has been observed in neuroinflammatory states such as multiple sclerosis and Alzheimer's disease (Lue et al., 1996; Vercellino et al., 2007). In Alzheimer's disease, loss of synaptic proteins has been correlated with neurological decline (Terry et al., 1991), whereas both iNOS and IL- $1 \beta$ signaling have been implicated in the loss of synaptic proteins in mouse models of
Alzheimer's disease (Craft et al., 2005; Medeiros et al., 2007). Here we show that injection of LPS into the mouse striatum resulted in a marked loss of synapsin. Although the precise mechanism of this synaptic alteration remains to be determined, we have shown that it can be prevented by neutralization of the Nox 1 gene. This finding is consistent with the Nox1-enhanced microglial expression of IL-1 $\beta$ and iNOS and establishes that Noxl may cause synaptic damage in a neuroinflammatory lesion. Recent studies in a mouse model of human ALS in which motoneurons progressively degenerate show that activated microglia accelerate disease progression (Boillée et al., 2006), whereas invalidation of Nox1 retards progression (Marden et al., 2007). We speculate that Nox1 may favor neural cell damage in ALS or other CNS diseases by promoting microglial production of cytotoxic effectors.

In conclusion, this study shows that in addition to the Nox2-dependent phagocyte oxidase, microglia express a Nox1 oxidase that catalyzes intracellular and intraphagosomal production of $\mathrm{O}_{2}{ }^{\cdot-}$. Nox1 and Nox2 differentially promote microglial production of proinflammatory and potentially cytotoxic compounds. Activation of microglial Nox1 may therefore contribute to immune defenses, neuroregressive events during neurogenesis, and the neural tissue damage that occurs in neurodegenerative or inflammatory diseases. These issues deserve further investigation.

\section{References}

Allan SM, Tyrrell PJ, Rothwell NJ (2005) Interleukin- 1 and neuronal injury. Nat Rev Immunol 5:629-640.

Ambasta RK, Kumar P, Griendling KK, Schmidt HH, Busse R, Brandes RP (2004) Direct interaction of the novel Nox proteins with $\mathrm{p} 22$ phox is required for the formation of a functionally active NADPH oxidase. J Biol Chem 279:45935-45941.

Arai H, Furuya T, Yasuda T, Miura M, Mizuno Y, Mochizuki H (2004) Neurotoxic effects of lipopolysaccharide on nigral dopaminergic neurons are mediated by microglial activation, interleukin-1beta, and expression of caspase-11 in mice. J Biol Chem 279:51647-51653.

Bánfi B, Clark RA, Steger K, Krause KH (2003) Two novel proteins activate superoxide generation by the NADPH oxidase NOX1. J Biol Chem 278:3510-3513.

Bedard K, Krause KH (2007) The NOX family of ROS-generating NADPH oxidases: physiology and pathophysiology. Physiol Rev 87:245-313.

Bianca VD, Dusi S, Bianchini E, Dal Prà I, Rossi F (1999) beta-amyloid activates the O-2 forming NADPH oxidase in microglia, monocytes, and neutrophils. A possible inflammatory mechanism of neuronal damage in Alzheimer's disease. J Biol Chem 274:15493-15499.

Bindokas VP, Jordán J, Lee CC, Miller RJ (1996) Superoxide production in rat hippocampal neurons: selective imaging with hydroethidine. J Neurosci $16: 1324-1336$.

Block ML, Zecca L, Hong JS (2007) Microglia-mediated neurotoxicity: uncovering the molecular mechanisms. Nat Rev Neurosci 8:57-69.

Boillée S, Yamanaka K, Lobsiger CS, Copeland NG, Jenkins NA, Kassiotis G, 
Kollias G, Cleveland DW (2006) Onset and progression in inherited ALS determined by motor neurons and microglia. Science 312:1389-1392.

Cai Z, Pang Y, Lin S, Rhodes PG (2003) Differential roles of tumor necrosis factor-alpha and interleukin-1 beta in lipopolysaccharide-induced brain injury in the neonatal rat. Brain Res 975:37-47.

Campion Y, Paclet MH, Jesaitis AJ, Marques B, Grichine A, Berthier S, Lenormand JL, Lardy B, Stasia MJ, Morel F (2007) New insights into the membrane topology of the phagocyte NADPH oxidase: characterization of an anti-gp91-phox conformational monoclonal antibody. Biochimie 89:1145-1158.

Choi HB, Ryu JK, Kim SU, McLarnon JG (2007) Modulation of the purinergic P2X7 receptor attenuates lipopolysaccharide-mediated microglial activation and neuronal damage in inflamed brain. J Neurosci 27:4957-4968.

Craft JM, Watterson DM, Hirsch E, Van Eldik LJ (2005) Interleukin 1 receptor antagonist knockout mice show enhanced microglial activation and neuronal damage induced by intracerebroventricular infusion of human beta-amyloid. J Neuroinflammation 2:15.

DeLeo FR, Burritt JB, Yu L, Jesaitis AJ, Dinauer MC, Nauseef WM (2000) Processing and maturation of flavocytochrome b558 include incorporation of heme as a prerequisite for heterodimer assembly. J Biol Chem 275:13986-13993.

Doussiere J, Gaillard J, Vignais PV (1999) The heme component of the neutrophil NADPH oxidase complex is a target for aryliodonium compounds. Biochemistry 38:3694-3703.

Dröge W (2002) Free radicals in the physiological control of cell function. Physiol Rev 82:47-95.

Ferreira A, Rapoport M (2002) The synapsins: beyond the regulation of neurotransmitter release. Cell Mol Life Sci 59:589-595.

Fiebich BL, Butcher RD, Gebicke-Haerter PJ (1998) Protein kinase $\mathrm{C}$-mediated regulation of inducible nitric oxide synthase expression in cultured microglial cells. J Neuroimmunol 92:170-178.

Gavazzi G, Banfi B, Deffert C, Fiette L, Schappi M, Herrmann F, Krause KH (2006) Decreased blood pressure in NOX1-deficient mice. FEBS Lett 580:497-504.

Halliwell B (2006) Oxidative stress and neurodegeneration: where are we now? J Neurochem 97:1634-1658.

Hanisch UK, Kettenmann H (2007) Microglia: active sensor and versatile effector cells in the normal and pathologic brain. Nat Neurosci 10:1387-1394.

Harrigan TJ, Abdullaev IF, Jourd'heuil D, Mongin AA (2008) Activation of microglia with zymosan promotes excitatory amino acid release via volume-regulated anion channels: the role of NADPH oxidases. J Neurochem 106:2449-2462.

Hill KE, Zollinger LV, Watt HE, Carlson NG, Rose JW (2004) Inducible nitric oxide synthase in chronic active multiple sclerosis plaques: distribution, cellular expression and association with myelin damage. J Neuroimmunol 151:171-179.

Hunter T (2000) Signaling —2000 and beyond. Cell 100:113-127.

Ibi M, Matsuno K, Shiba D, Katsuyama M, Iwata K, Kakehi T, Nakagawa T, Sango K, Shirai Y, Yokoyama T, Kaneko S, Saito N, Yabe-Nishimura C (2008) Reactive oxygen species derived from NOX1/NADPH oxidase enhance inflammatory pain. J Neurosci 28:9486-9494.

Iravani MM, Kashefi K, Mander P, Rose S, Jenner P (2002) Involvement of inducible nitric oxide synthase in inflammation-induced dopaminergic neurodegeneration. Neuroscience 110:49-58.

Jung S, Aliberti J, Graemmel P, Sunshine MJ, Kreutzberg GW, Sher A, Littman DR (2000) Analysis of fractalkine receptor CX(3)CR1 function by targeted deletion and green fluorescent protein reporter gene insertion. Mol Cell Biol 20:4106-4114.

Kawahara T, Ritsick D, Cheng G, Lambeth JD (2005) Point mutations in the proline-rich region of p22phox are dominant inhibitors of Nox1- and Nox2-dependent reactive oxygen generation. J Biol Chem 280:31859-31869.

Lambeth JD, Kawahara T, Diebold B (2007) Regulation of Nox and Duox enzymatic activity and expression. Free Radic Biol Med 43:319-331.

Lehnardt S, Massillon L, Follett P, Jensen FE, Ratan R, Rosenberg PA, Volpe JJ, Vartanian T (2003) Activation of innate immunity in the CNS triggers neurodegeneration through a Toll-like receptor 4-dependent pathway. Proc Natl Acad Sci U S A 100:8514-8519.

Li J, Baud O, Vartanian T, Volpe JJ, Rosenberg PA (2005) Peroxynitrite generated by inducible nitric oxide synthase and NADPH oxidase mediates microglial toxicity to oligodendrocytes. Proc Natl Acad Sci U S A 102:9936-9941.

Lue LF, Brachova L, Civin WH, Rogers J (1996) Inflammation, A beta deposition, and neurofibrillary tangle formation as correlates of Alzheimer's disease neurodegeneration. J Neuropathol Exp Neurol 55:1083-1088.

Ma XC, Gottschall PE, Chen LT, Wiranowska M, Phelps CP (2002) Role and mechanisms of interleukin-1 in the modulation of neurotoxicity. Neuroimmunomodulation 10:199-207.

Mander PK, Jekabsone A, Brown GC (2006) Microglia proliferation is regulated by hydrogen peroxide from $\mathrm{NADPH}$ oxidase. J Immunol 176:1046-1052.

Marden JJ, Harraz MM, Williams AJ, Nelson K, Luo M, Paulson H, Engelhardt JF (2007) Redox modifier genes in amyotrophic lateral sclerosis in mice. J Clin Invest 117:2913-2919.

Marín-Teva JL, Dusart I, Colin C, Gervais A, van Rooijen N, Mallat M (2004) Microglia promote the death of developing Purkinje cells. Neuron 41:535-547.

Medeiros R, Prediger RD, Passos GF, Pandolfo P, Duarte FS, Franco JL, Dafre AL, Di Giunta G, Figueiredo CP, Takahashi RN, Campos MM, Calixto JB (2007) Connecting TNF- $\alpha$ signaling pathways to iNOS expression in a mouse model of Alzheimer's disease: relevance for the behavioral and synaptic deficits induced by amyloid $\beta$ protein. J Neurosci 27:5394-5404.

Miletic AV, Graham DB, Montgrain V, Fujikawa K, Kloeppel T, Brim K, Weaver B, Schreiber R, Xavier R, Swat W (2007) Vav proteins control MyD88-dependent oxidative burst. Blood 109:3360-3368.

Nauseef WM (2007) How human neutrophils kill and degrade microbes: an integrated view. Immunol Rev 219:88-102.

O'Neill LA, Bowie AG (2007) The family of five: TIR-domain-containing adaptors in Toll-like receptor signalling. Nat Rev Immunol 7:353-364.

Parkos CA, Dinauer MC, Jesaitis AJ, Orkin SH, Curnutte JT (1989) Absence of both the $91 \mathrm{kD}$ and $22 \mathrm{kD}$ subunits of human neutrophil cytochrome b in two genetic forms of chronic granulomatous disease. Blood 73:1416-1420.

Pawate S, Shen Q, Fan F, Bhat NR (2004) Redox regulation of glial inflammatory response to lipopolysaccharide and interferongamma. J Neurosci Res 77:540-551.

Philippe S, Sarkis C, Barkats M, Mammeri H, Ladroue C, Petit C, Mallet J, Serguera C (2006) Lentiviral vectors with a defective integrase allow efficient and sustained transgene expression in vitro and in vivo. Proc Natl Acad Sci U S A 103:17684-17689.

Pollock JD, Williams DA, Gifford MA, Li LL, Du X, Fisherman J, Orkin SH, Doerschuk CM, Dinauer MC (1995) Mouse model of X-linked chronic granulomatous disease, an inherited defect in phagocyte superoxide production. Nat Genet 9:202-209.

Qin B, Cartier L, Dubois-Dauphin M, Li B, Serrander L, Krause KH (2006) A key role for the microglial NADPH oxidase in APP-dependent killing of neurons. Neurobiol Aging 27:1577-1587.

Qin L, Liu Y, Wang T, Wei SJ, Block ML, Wilson B, Liu B, Hong JS (2004) NADPH oxidase mediates lipopolysaccharide-induced neurotoxicity and proinflammatory gene expression in activated microglia. J Biol Chem 279:1415-1421.

Qin L, Li G, Qian X, Liu Y, Wu X, Liu B, Hong JS, Block ML (2005) Interactive role of the toll-like receptor 4 and reactive oxygen species in LPSinduced microglia activation. Glia 52:78-84.

Qin S, Colin C, Hinners I, Gervais A, Cheret C, Mallat M (2006) System Xcand apolipoprotein $\mathrm{E}$ expressed by microglia have opposite effects on the neurotoxicity of amyloid- $\beta$ peptide 1-40. J Neurosci 26:3345-3356.

Reeves EP, Lu H, Jacobs HL, Messina CG, Bolsover S, Gabella G, Potma EO, Warley A, Roes J, Segal AW (2002) Killing activity of neutrophils is mediated through activation of proteases by K+ flux. Nature 416:291-297.

Rock RB, Gekker G, Hu S, Sheng WS, Cheeran M, Lokensgard JR, Peterson PK (2004) Role of microglia in central nervous system infections. Clin Microbiol Rev 17:942-964, table of contents.

Sankarapandi S, Zweier JL, Mukherjee G, Quinn MT, Huso DL (1998) Measurement and characterization of superoxide generation in microglial cells: evidence for an NADPH oxidase-dependent pathway. Arch Biochem Biophys 353:312-321.

Serrander L, Cartier L, Bedard K, Banfi B, Lardy B, Plastre O, Sienkiewicz A, Fórró L, Schlegel W, Krause KH (2007) NOX4 activity is determined by mRNA levels and reveals a unique pattern of ROS generation. Biochem J 406:105-114. 
Stolk J, Hiltermann TJ, Dijkman JH, Verhoeven AJ (1994) Characteristics of the inhibition of NADPH oxidase activation in neutrophils by apocynin, a methoxy-substituted catechol. Am J Respir Cell Mol Biol 11:95-102.

Stuehr DJ, Fasehun OA, Kwon NS, Gross SS, Gonzalez JA, Levi R, Nathan CF (1991) Inhibition of macrophage and endothelial cell nitric oxide synthase by diphenyleneiodonium and its analogs. FASEB J 5:98-103.

Suh YA, Arnold RS, Lassegue B, Shi J, Xu X, Sorescu D, Chung AB, Griendling KK, Lambeth JD (1999) Cell transformation by the superoxidegenerating oxidase Mox1. Nature 401:79-82.

Szabó C, Ischiropoulos H, Radi R (2007) Peroxynitrite: biochemistry, pathophysiology and development of therapeutics. Nat Rev Drug Discov 6:662-680.

Terry RD, Masliah E, Salmon DP, Butters N, DeTeresa R, Hill R, Hansen LA, Katzman R (1991) Physical basis of cognitive alterations in Alzheimer's disease: synapse loss is the major correlate of cognitive impairment. Ann Neurol 30:572-580.

Tew DG (1993) Inhibition of cytochrome P450 reductase by the diphenyliodonium cation. Kinetic analysis and covalent modifications. Biochemistry 32:10209-10215.

Théry C, Chamak B, Mallat M (1991) Cytotoxic effect of brain macrophages on developing neurons. Eur J Neurosci 3:1155-1164.

Tomás-Camardiel M, Rite I, Herrera AJ, de Pablos RM, Cano J, Machado A, Venero JL (2004) Minocycline reduces the lipopolysaccharide-induced inflammatory reaction, peroxynitrite-mediated nitration of proteins, disruption of the blood-brain barrier, and damage in the nigral dopaminergic system. Neurobiol Dis 16:190-201.

Torreilles F, Salman-Tabcheh S, Guérin M, Torreilles J (1999) Neurodegenerative disorders: the role of peroxynitrite. Brain Res Brain Res Rev 30:153-163.

Veal EA, Day AM, Morgan BA (2007) Hydrogen peroxide sensing and signaling. Mol Cell 26:1-14.

Vercellino M, Merola A, Piacentino C, Votta B, Capello E, Mancardi GL, Mutani R, Giordana MT, Cavalla P (2007) Altered glutamate reuptake in relapsing-remitting and secondary progressive multiple sclerosis cor- tex: correlation with microglia infiltration, demyelination, and neuronal and synaptic damage. J Neuropathol Exp Neurol 66:732-739.

Wakselman S, Béchade C, Roumier A, Bernard D, Triller A, Bessis A (2008) Developmental neuronal death in hippocampus requires the microglial CD11b integrin and DAP12 immunoreceptor. J Neurosci 28:8138-8143.

Walder CE, Green SP, Darbonne WC, Mathias J, Rae J, Dinauer MC, Curnutte JT, Thomas GR (1997) Ischemic stroke injury is reduced in mice lacking a functional NADPH oxidase. Stroke 28:2252-2258.

Wilkinson B, Koenigsknecht-Talboo J, Grommes C, Lee CY, Landreth G (2006) Fibrillar beta-amyloid-stimulated intracellular signaling cascades require Vav for induction of respiratory burst and phagocytosis in monocytes and microglia. J Biol Chem 281:20842-20850.

Wu DC, Teismann P, Tieu K, Vila M, Jackson-Lewis V, Ischiropoulos H, Przedborski S (2003) NADPH oxidase mediates oxidative stress in the 1-methyl-4-phenyl-1,2,3,6-tetrahydropyridine model of Parkinson's disease. Proc Natl Acad Sci U S A 100:6145-6150.

Wu DC, Ré DB, Nagai M, Ischiropoulos H, Przedborski S (2006) The inflammatory NADPH oxidase enzyme modulates motor neuron degeneration in amyotrophic lateral sclerosis mice. Proc Natl Acad Sci U S A 103:12132-12137.

Xie Z, Wei M, Morgan TE, Fabrizio P, Han D, Finch CE, Longo VD (2002) Peroxynitrite mediates neurotoxicity of amyloid $\beta$-peptide1-42- and lipopolysaccharide-activated microglia. J Neurosci 22:3484-3492.

Zaidi A, Michaelis ML (1999) Effects of reactive oxygen species on brain synaptic plasma membrane $\mathrm{Ca}(2+)$-ATPase. Free Radic Biol Med 27:810-821.

Zhang W, Wang T, Pei Z, Miller DS, Wu X, Block ML, Wilson B, Zhang W, Zhou Y, Hong JS, Zhang J (2005) Aggregated alpha-synuclein activates microglia: a process leading to disease progression in Parkinson's disease. FASEB J 19:533-542.

Zito MA, Koennecke LA, McAuliffe MJ, McNally B, van Rooijen N, Heyes MP (2001) Depletion of systemic macrophages by liposome-encapsulated clodronate attenuates striatal macrophage invasion and neurodegeneration following local endotoxin infusion in gerbils. Brain Res 892:13-26. 